\title{
Avrupa Birliği’nin Siber Güvenlik Politikası: Kurumsalcılık mı Tutarlılık mı?
}

\author{
The Cyber Security Policy of European Union: \\ Institutionalism or Coherence?
}

Fulya KÖKSOY*

\section{$\ddot{O} z$}

Bilgi ve iletişim teknolojilerinin özellikle son dönemde hayatımıza yoğunluklu olarak entegre olduğu görülmektedir. Dijital çağın önüne geçilemez bir hızla değişim ve dönüşüm geçirmesi, pek çok avantaja neden olsa da beraberinde risk ve tehditleri getirmektedir. Öyle ki siber saldırlar bireylere, kurumlara ve devletlere yönelik önemli bir tehdit oluşturmaktadır. Bu bağlamda, son derece kırılgan bir dünya kompozisyonu ile karşılaşılmakta ve siber güvenlik kavramı ön plana çıkmaktadır. Siber güvenliğin sağlanması hususunun son derece önemli olmast çerçevesinde Avrupa Birliği (AB) de dijitalleşen dünyadan kaynaklanan tehditleri kabul eden ve siber alanın güvenliğini sağlamaya dönük stratejiler ve politikalar geliştirmeye çalışan bir aktördür. Bu minvalden hareketle çalışmada, uluslararasi sistemde kendine münhastr bir muhtevaya sahip olan ve 1 Aralı 2009 tarihinde yürürlüğe giren Lizbon Antlaşmast ile beraber tüzel kişilik kazanan Avrupa Birliği’nin siber güvenlik politikaları analiz edilmekte, $A B$ ile siber güvenlik olgusu bağlamında nasıl bir denklem ortaya çıkmaktadır? sorusuna cevap aranmakta ve bu denklemin, resmî (kurumlar) ve gayri resmî (kurallar, prosedürler gibi) yapılar ekseninde AB'nin siber güvenlik politikasının analiz edilmesini sağlayan kurumsalcılık mı yoksa tutarlılık bağlamında mı kurulduğuna odaklanılmaktadır.

\footnotetext{
* Dr. Öğr. Üyesi, Batman Üniversitesi, İktisadi ve İdari Bilimler Fakültesi Uluslararası İlişkiler Bölümü, ORCID: 0000-0002-6915-5620, e-posta: fulya.koksoy@ batman.edu.tr. 
636

Güvenlik Stratejileri

Cilt: 16

Sayı: 35

Anahtar Kelimeler: Avrupa Birliği, Siber Güvenlik, Tarihsel Kurumsalcılık, Tutarlılık, Avrupa Birliği'nin Siber Güvenlik Politikası.

\section{Abstract}

It is seen that information and communication technologies have been intensely integrated into our lives especially in the recent period. The digital age has been changed and transformed at an unavoidable rate, despite it causes many advantages, but it also brings risks and threats. In fact, cyber-attacks pose an important threat to individuals, institutions and states. In this context, an extremely fragile world composition is encountered and the concept of cyber security comes to the fore. As the issue of ensuring cyber security is extremely important, the European Union (EU) is an actor that accepts threats arising from the digital world and tries to develop strategies and policies to ensure the security of the cyber space. Concordantly, the cyber security policies of the European Union, which has sui-generis content in the international system and gained legal status by Lisbon treaty entered into force on 1 December 2009, are analyzed. In addition to this, the equation arises between the European Union and the cyber security phenomenon has been examined for finding out whether the equation is built on institutionalism, which enables the analysis of the EU's cyber security policy on the basis of formal (institutions) and informal (such as rules, procedures) structures, or consistency.

Keywords: European Union, Cyber Security, Historical Institutionalism, Coherence, European Union's Cyber Security Policy.

\section{Giriş}

Çağdaş güvenlik yaklaşımları içerisinde kendine yer edinen iki önemli kavram söz konusudur: siber ve bu doğrultuda siber güvenlik. Güvenliğe ilişkin literatür analiz edildiği takdirde, özellikle son birkaç yıldır siber olgusu üzerine odaklanıldığı görülmektedir. Bilgi ve iletişim teknolojilerinin çığır açan bir boyutta gelişim göstermesini takiben, güvenlik ve siber alan ortak bir payda da buluşmakta ve son dönemde söz konusu alana yönelik ilgi peyderpey artmaktadır. Bu kapsamda günümüzde uluslararası sistemde yer alan 
Avrupa Birliği’nin Siber Güvenlik Politikası:

Kurumsalcılık mı Tutarlılık mı?

irili ufaklı birçok devletin yanı sıra, Kuzey Atlantik Anlaşması Örgütü (North Atlantic Treaty Organization/NATO) veya ve ya AB gibi uluslararası örgütlerin de kendi siber güvenlik strateji planlamalarını hazırlamaya başlamışlardır. Bununla birlikte NATO'ya kıyasla AB'nin siber güvenlik politikasına ilişkin yapılan çalışmalar ise bugüne kadar sınırlı düzeyde kalmıştır. ${ }^{1}$ Bir diğer ifadeyle, ilgili literatür analiz edildiğinde $\mathrm{AB}$ 'nin ekonomi, dış politika, savunma, güvenlik, çevre ve finans gibi çeşitli alanlardaki politikalarına yönelik birçok çalışmanın olduğu fakat siber güvenlik alanındaki politikalarına ilişkin literatürün kısır kaldığı ve önemli bir boşluk olduğu gözlemlenmektedir. Mevzubahis boşluğun analiz edilmesi amacıyla ortaya konan bu çalışmanın özünde AB'nin siber güvenlik politikası incelenmekte, Tarihsel Kurumsalcılık kuramı ve Tutarlılık yaklaşımı/modeli çerçevesinde söz konusu politikanın ne yönde bir gelişim gösterdiği (kurumsallaşma ve/veya tutarlılık) sorunsallaştırılmaktadır.

Yeni Kurumsalcılık kuramı altında yer alan Tarihsel Kurumsalcılık teorisi ekseninde, AB'nin siber güvenlik alanına hangi açıdan -askerî, sosyal, ekonomik vb- yaklaştığı ve zaman kavramına odaklanan kuram bağlamında söz konusu yaklaşımda herhangi bir değişim yaşanıp yaşanmadığı, siber güvenlik alanında faaliyet gösteren kurumların, kurumsal düzenlemelerin ve siber güvenlik politikasıyla ulaşılmak istenen hedeflerin geçmişten günümüze nasıl bir gelişim gösterdiği analiz edilmektedir. Bu noktada, kronolojik bir düzlemde AB'nin bilgi ve iletişim teknolojilerine yönelik ilgisinin başlangıç noktasını oluşturan 1985 y1lındaki "Beyaz Kitap’tan” 2019 y1lında yürürlüğe giren "Siber Güvenlik Yasası'na" kadar geçen 34 yılda ortaya konan ilgili dokümanlar içerik analizine tabi tutulmaktadır. 2013 yılında Avrupa Komisyonu tarafindan yayımlanan "Siber Güvenlik Strateji Belgesi", AB'nin siber güvenlik politikasının somut bir zemine oturmasında önem arz ettiği için öncelikle söz konusu belge ayrıntılı olarak incelenerek, diğer

${ }^{1}$ Ali B. Darıcıll, "Türkiye'nin Siber Güvenlik Politikalarının Analizi; Türkiye'nin Siber Güvenlik Modeli için Öneriler”, TESAM Akademi Dergisi, 2019, Cilt 6, Sayı 2, 11-33, s. 14. 
Güvenlik Stratejileri

Cilt: 16

Sayı: 35

belgelerin içerik analizinde kullanılacak kodlar elde edilmiştir. AB'nin yaklaşımı bağlamında sosyo-ekonomi kavramı, hedefleri ekseninde ise ekonomi, güven, dijital, temel haklar, siber suçların önlenmesi ve iş birliği kavramları ekseninde bir kodlama listesi oluşturularak söz konusu analiz pratik boyuta taşınmıştır.

Öte yandan, geniş bir politika spektrumu içerisinde yer alan AB'nin, siber güvenlik alanında hem üzerine inşa edildiği statik yapıya rağmen değişim ve dönüşüm odaklı yaptığı retorik vurgu hem de siber güvenlik alanında rol oynayan oyuncular ve enstrümanlar çerçevesinde karmaşık bir aktör portresi çizdiği görülmektedir. Söz konusu bu karmaşı yapı ise bir bütün olarak güvenlik özel de ise siber güvenlik alanında tutarlılığın olması gerekliliğinin altını çizmektedir. $\mathrm{Bu}$ doğrultuda, $\mathrm{AB}$ siber güvenlik alanında tutarlı bir aktör olarak değerlendirilebilir mi? sorusuna cevap aranmaktadır. Bir diğer ifadeyle, AB'nin tutarlılığının analiz edilmesi ve bunu siber güvenlik alanına yansıtma amacı söz konusudur.

Ortaya konan bu şablon ekseninde çalışmanın ilgili bölümleri gün yüzüne çıkmaktadır. $\mathrm{Bu}$ noktada ilk bölümde, $\mathrm{AB}$ bağlamında siber güvenliğe ilişkin ortak bir kavramsallaştırma olup olmadığı analiz edilmektedir. Daha sonra çalışmanın üzerine inşa edildiği tarihsel kurumsalc1lık teorisine ve tutarlılık yaklaşımına ilişkin teorik çerçeve çizilmektedir. Üçüncü bölümde; yaklaşım, uygulama ve hedefler bağlamında AB'nin siber güvenlik politikalarının kronolojik bir düzlemde analizi sonrası, son kısımda ise söz konusu politika tarihsel kurumsalcılık ve tutarlık yaklaşımı çerçevesinde analiz edilerek, çalışmaya adını veren "AB'nin Siber Güvenlik Politikaları: Kurumsalcılık mı Tutarlılık mı?" sorusuna cevap aranmaktadır.

\section{Avrupa Birliği Ekseninde Siber Güvenliğin Kavramsallaştırılması: Ortak Bir Siber Güvenlik Tanımı Var mı?}

Siber uzay; yeni, karmaşık, çok boyutlu ve tam anlamıyla keşfedilemeyen bir alanı teşkil etmektedir. Bir bütün olarak siberin çok boyutlu ve küresel doğası çerçevesinde siberden doğan terimlere ilişkin 
Avrupa Birliği’nin Siber Güvenlik Politikası:

Kurumsalcılık mı Tutarlılık mı?

somut manada kabul gören bir tanımlama bulunmamaktadır. ${ }^{2} \mathrm{Bu}$ noktada, siber uzay terimini kavramsallaştırma çabası, benzer şekilde siber güvenlik terimi bağlamında da devam etmektedir.

İlgili literatür analiz edildiği takdirde; devletler, uluslararası örgütler, bölgesel örgütler gibi çeşitli aktörlerin siber güvenliğe ilişkin bir tanımlama yapmaya çalıştıkları görülmektedir. ${ }^{3} \mathrm{AB}$ ekseninde ise siber güvenliğe yönelik bütüncül bir anlayış ve kolektif bir vizyonu içeren, ortak bir tanım yapılmamıştır. Nitekim AB'nin siber güvenlikle ilişkili temel belgesi olan ve 7 Şubat 2013 tarihinde Komisyon tarafindan yayımlanan "Avrupa Birliği'nin Siber Güvenlik Strateji” (Cybersecurity Strategy of the European Union: An Open, Safe and Secure Cyberspace) belgesinde, söz konusu stratejinin 2017 y1lında revize edilmiş versiyonunda (Resillience, Deterrence and Defence:Building Strong Cybersecurity for the EU) ve 11 Mart 2019 tarihinde Avrupa Parlamentosu'nda onaylanan ve 27 Haziran 2019 tarihinde yürürlüğe giren "Siber Güvenlik Yasası" (Cyber Security Act) içinde siber güvenlik tanımı bulunmamaktadır. Ancak AB'ye bağlı, ağ ve bilgi güvenliğinden sorumlu olan Avrupa Ağ ve Bilgi Güvenliği Ajans1, (European Network and Information Security Agency-ENISA) siber güvenliği tanımlamıştır. Söz konusu tanım çerçevesinde siber güvenlik; " bilgi, bilgi sistemleri, altyapılar ve uygulanmaların siber tehdit ve saldırılardan korunmasıdır". 4 Ayrıca şekil 1'de görüldüğü gibi ENISA tarafindan siber güvenliğin korunmasına yönelik katmanlara ayrılan bir piramit ortaya konmaktadır.

\footnotetext{
${ }^{2}$ Dan Craigen vd., "Defining Cybersecurity", Technology Innovation Management Review, 2014, p.1, https://timreview.ca/sites/default/files/article_PDF/Craigen_et_al_ TIMReview_October2014.pdf, (Erişim Tarihi: 18.02.2020).

${ }^{3}$ Ibid.

${ }^{4}$ Udo Helmbrecht vd., "Cyber Security: Future Challenges and Oportunities", 2012, p.13, https://www.btg.org/wp-content/uploads/2012/01/ENISA-Cyber-Security-Report-2011.pdf, (Erişim Tarihi:03.05.2020).
}

\section{9}

Güvenlik Stratejileri

Cilt: 16

Say1: 35 
640

Güvenlik Stratejileri

Cilt: 16

Sayı: 35

\section{Şekil 1: Siber Güvenlik Katmanları}

Demokrasi ve İnsan Haklarının Korunması

Siber etik, siber demokrasi, siber insan

hakları ve $A B$ değererinin korunması

Küresel İstikrarın Korunması

Siber normlarm ve siber diplomasinin tesis edilmesi

Dijital Tek Pazarm Korunması

Dijital tek pazarm siber saldırlardan korunması

Kritik Altyapıların Korunması

Enerji, ulașım, finans gibi dijital hizmetlerin korunması

Temel Güvenlik Önlemleri

Siber uzay kullanıcılarının güvenliğinin sağlanması

ENISA tarafindan siber güvenliğin korunmasına ilişkin ortaya konulan bu piramit ekseninde belirtmek gerekir ki siber güvenlik şemsiye bir kavramı teșkil etmekte ve bu doğrultuda resmî ve genel kabul gören bir tanım ortaya konulamamaktadır. Ancak bu yaklaşımın, siber güvenliği tanımlamaya yönelik somut bir çabayı teşkil ettiği görülmektedir.

Öte yandan, $\mathrm{AB}$ üye devletlerinin siber güvenliğe ilişkin kendi stratejileri ve kavramsallaştırmaları bulunmaktadır. ${ }^{6}$ Bir diğer ifadeyle, birçok $\mathrm{AB}$ üyesi siber güvenliği kendince tanımlamaktadır. Ancak söz konusu bu durum ekseninde sorun yaşanmaktadır. Örneğin, Almanya'ya göre siber güvenlik; siber uzayın kullanılabilirliğinin sağlanması, siber

5 ENISA, "Overview of Cybersecurity and Related Terminology", 2017, https://www.enisa.europa.eu/publications/enisa-positionpapers-and-opinions/enisa-ove rview-of-cybersecurity-and-related-terminology, (Erişim Tarihi:03.05.2020).

${ }^{6}$ Feliks Sliwinski, "Moving beyond the European Union's Weakness as a Cyber Security Agent", Contemporary Security Policy, 2014, Vol 35, No 3, 468-486, p. 468. 
Avrupa Birliği’nin Siber Güvenlik Politikası:

Kurumsalcılık mı Tutarlılık mı?

uzaydaki verilerin bütünlüğü, özgünlüğü ve gizliliğinin korunmas1 ${ }^{7}$ anlamına gelirken Polonya somut bir tanım ortaya koymamıştır. ${ }^{8}$ Diğer taraftan, çok daha yeni bir tarih olan 2018 yılında revize edilen Çekya'nın siber güvenlik strateji belgesinde de siber güvenliğe ilişkin bir tanımın söz konusu olmadığı görülmektedir (Strategie Kybernetické Obrany $\check{C} R$, 2018). ${ }^{9}$ Üstüne üstlük, siber güvenliğe ilişkin üye devletlerin yaklaşımlarında da farklılık gözlemlenmektedir. Öyle ki Fransa askerî ve istihbarat temelli bir yaklaşım sergilerken Almanya ve Hollanda sivil ve hukuki odaklıdır. Estonya ise hem askerî ve istihbarat hem de sivil ve hukuki bir yaklaşım ortaya koymaktadır. ${ }^{10}$ Sonuç olarak, AB bağlamında terimin terminolojik olarak ortak bir payda da tanımlanması ve standartlaştırılmasında önemli bir boşluk olduğu görülmektedir.

\section{Teorik Çerçeve}

Avrupa Birliği ve siber güvenlik denkleminin analiz edilmesi noktasında bunun arka planındaki kurumsal dinamikleri ve AB'nin ne ölçüde tutarlılık gösterdiğini anlamak önem arz etmektedir. Bu noktada devreye, "Tarihsel Kurumsalcılık Teorisi" ve "Tutarlılık Yaklaşımı" girmektedir.

Çalışmanın üzerine inşa edildiği ana teori olan; kurumları resmî yapılar ve prosedürler, rutinler, normlar, sözleşmeler gibi gayri resmî yapılar ekseninde tanımlayan tarihsel kurumsalcılık, ${ }^{11}$ teoriye yönelik

\footnotetext{
${ }^{7}$ Federal Ministry of the Interior, "Cyber Security Strategy for Germany", p.4, https://www.cio.bund.de/SharedDocs/Publikationen/DE/Strategische-

Themen/css_engl_download.pdf?_blob=publicationFile, (Erişim Tarihi: 09.03.2020).

${ }^{8}$ Ministry of Digital Affairs, "National Framework of Cybersecurity Policy of the Republic of Poland for 2017-2022", 2017, https://www.enisa.europa.eu/topics/ national-cyber-security-strategies/ncssmap/strategies/govermental-program-for-protect ion-of-cyberspace-for-theyears-2011-2016-2013, (Erişim Tarihi:09.03.2020).

${ }^{9}$ Strategie Kybernetické Obrany ČR, 2018, http://www.acr.army.cz/assets/informacniservis/zpravodajstvi/strategie-kyberneticke-obrany.pdf, (Erişim Tarihi:07.05.2020).

${ }^{10}$ Nezir Akyeşilmen, Siber Politika ve Güvenlik, Orion Yayınevi, Ankara, 2018, s. 135.

${ }^{11}$ Peter Hall and Charles Taylor, "Political Science and the Three New Institutionalisms", Political Studies, 1996, Vol 44, No 2, 936-957, p. 938.
}

\section{1}

Güvenlik Stratejileri

Cilt: 16

Say1: 35 
642

Güvenlik Stratejileri

Cilt: 16

Say1: 35

birtakım mekanizmalar ortaya koymaktadır. Söz konusu teorinin ortaya koyduğu ilk mekanizma, içsel ve doğal çıkarlara ilişkin önemli soruları ele alması ve zaman kavramını odak noktası haline getirmesidir. ${ }^{12} \mathrm{Bu}$ noktada, kurumlar zaman içinde nasıl gelişmiştir?, kurumlar aktörlerin davranışları ve pozisyonlarını nasıl etkilemiştir? ${ }^{13}$ gibi sorular devreye girmektedir.

Öte yandan teori, kurumlar ve aktörler arasındaki ilişkiyi yol bağımlılığı/izlek bağımlılığı (path dependency) ekseninde ele almakta ancak beklenmeyen sonuçlar bağlamında kesintiye uğramış denge/noktalanmış denge (punctuated equlibrium) kavramını da ortaya koymaktadır. Yol bağımlılı̆̆ çerçevesinde tarihsel kurumsalcılığın temel savı, siyasi ve sosyal bir süreçte başlangiçta alınan kararların -yolu yeni bir yöne kaydırmak için kritik dönemeçler oluşana kadar- daha sonra alınan kararlar üzerinde etkili olmaya devam etmesidir. ${ }^{14} \mathrm{Bu}$ noktada, belirli zamanlama ve sıralama kalıplarının önem arz ettiği ve önceki kararların ve seçimlerin sonrakilerden öncelikli olduğu belirtilmekte ${ }^{15}$ ayrıca bir seçim yapıldıktan sonra, aktörlerin mevzubahis seçimleri değiştirmelerinin veya girdikleri yoldan sapmalarının zorlaştığı ifade edilmektedir. ${ }^{16}$ Bunun nedeni ise ilgili tüm aktörlerin politika seçimlerini/kararlarını hüküm süren yapıya uyum sağlanması noktasında ortaya çıkan "kenetlenme (lock-in) etkisi' dir". ${ }^{17} \mathrm{Bu}$ bağlamda

\footnotetext{
${ }^{12}$ Paul Pierson and Theda Skocpol, "Historical Institutionalism in Contemporary Political Science", Ira Katznelson, Helen Milner and Ada Finifter (Edt.), Political Science: The State of the Discipline, Norton Press, NewYork, 2002, 693-721, p. 695; Mark Pollack, "The New Institutionalism and European Integration", Antje Wiener and Thomas Diez (Edt.), European Integration Theory, Oxford University Press, NewYork, 2009, 125-143, p. 127.

${ }^{13}$ Mette Eilstrupp-Sangiovanni, Debates on European Integration, Palgrave, Houndmilss, 2006, p. 198.

${ }^{14}$ Hall and Taylor, "Political Science”, p. 941; Pollack, “The New Institutionalism”, p. 127.

${ }^{15}$ Paul Pierson, "Increasing Returns, Path Dependence, and the Study of Politics", American Political Science Association, 2000, Vol 94, No 2, 251-267, p. 251.

${ }^{16}$ Mark Pollack, "The New Institutionalism and EU Governance: The Promise and Limits of Institutionalist Analysis", Governance, 1996, Vol 9, No 4, 429-458, pp. 437-438.

17 Kathleen Thelen, "Historical Institutionalism in Comparative Politics", Annual Review of Political Science, 1999, Vol 2, pp. 369-404.
} 
Avrupa Birliği’nin Siber Güvenlik Politikası:

Kurumsalcılık mı Tutarlılık mı?

yol bağımlılığ 1 " "politika eylemsizliği” veya "değişime karşı direnç" ile karakterize olsa da -bir diğer anlatımla, önceki kurumsal ve siyasa tercihlerinin kalıcılığı ve israrcılığı üzerine odaklansa da- ${ }^{18}$ tarihsel kurumsalcılık nezdinde politika yollarının/kararlarının/tercihlerinin değişebileceği veya yeniden tanımlanabileceği bir mekanizma da bulunmaktadır. Söz konusu mekanizma kesintiye uğramış denge olarak tanımlanmaktadır $\mathrm{ki}^{19}$ buradaki ana unsur bir politika yolundan giderken kritik dönemeçlerin/katalitik olayların meydana gelmesidir. $\mathrm{Bu}$ dönemeçler, seçimlerin yeniden değerlendirilmesine ve yeni politikalara gidilmesine neden olmaktadır. ${ }^{20}$

Teorinin ortaya koyduğu bir diğer kavram ise olumlu geri bildirim döngüsüdür (positive feedback loop). Kavram, bir kurumun faaliyetleri ekseninde olumlu geri bildirimler aldığını belirtmektedir. Söz konusu olumlu geri bildirim doğrultusunda, kurumun uzmanlık ve iş birliği merkezi olarak yetkilerinin artabileceği bir döngünün oluştuğu ifade edilmektedir. Diğer yandan yol bağımlılı̆̆ı, olumlu geri bildirim sergileyen sosyal süreçler olarak tanımlanmaktadır. $\mathrm{Bu}$ bağlamda olumlu geri bildirimin, bir yolda gidilmesine yönelik alınan kararların -bir kurumun kurulması, bir politikanın uygulanması gibidaha güçlü bir şekilde devam etmesinde etkili olduğu vurgulanmaktadır. ${ }^{21}$

Çalışmanın bir diğer odak noktası ise tutarlılık yaklaşımıdır. Tutarlılı, AB projesi yapımının merkezinde konumlandırılan, hem politika yapım süreçleri hem de akademik tartışmaların gündeminde

\footnotetext{
${ }^{18}$ Pierson, "Inreasing Returns", p. 259.

19 Stephen D. Krasner,"Approaches to the State: Alternative Conceptions and Historical Dynamics", Comparative Politics, 1984, Vol 16, No 2, 223-246, p. 240.

${ }^{20}$ R. Berrins Collier and David Collier, "Framework: Critical Junctures and Historical Legacies", 1991, https://polisci.berkeley.edu/sites/default/files/people/u3827/CollierCollier\%20SPA\%20Chap\%201.pdf, (Erişim Tarihi: 10.04.2020).

${ }^{21}$ Paul Pierson, Politics in Time: History, Institutions, and Social Analysis, Princeton University Press, NJ., 2004, pp. 20-21; Matthew Lockwood vd., "Historical Institutionalism and the Politics of Sustainable Energy Transitions: A Research Agenda", 2016, https://core.ac.uk/download/pdf/43098859.pdf, (Erişim Tarihi: 19.02.2020).
}

\section{3}

Güvenlik Stratejileri

Cilt: 16

Say1: 35 
644

Güvenlik Stratejileri

Cilt: 16

Sayı: 35

yer alan önemli bir başlıktır. ${ }^{22} \mathrm{AB}$ Komisyonuna göre tutarlılık, daha iyi stratejik planlama yapılması, çok daha etkili olma, kurumlar ve aktörler arasında iş birliğinin oluştururulması ile eşit olan bir kavrama işaret etmektedir. ${ }^{23} \mathrm{AB}$ güvenlik stratejisi içerisinde ise tutarlılık, farklı enstrümanların ve kapasitelerin bir araya getirilmesi, $A B$ ve üye devletler arasında koordinasyonun sağlanması ve uyum içinde olunması olarak tanımlanmaktadır. ${ }^{24}$ Ancak, AB'nin tutarlı bir güvenlik aktörü olması beklentisi çerçevesinde teori ve pratikte önemli bir boşluk olduğu görülmektedir.

$\mathrm{Bu}$ çalışmada tutarlılık yaklaşımı, yatay ( $\mathrm{AB}$ kurumları, üye devletler ve özel sektör bünyesindeki politikalar ekseninde tutarlılık) ve dikey ( $\mathrm{AB}$ kurumları, üye devletler ve sektör arasındaki ilişkiler bağlamında tutarlılık) eksen çerçevesinde kurumsal koordinasyon ve ortak güvenlik anlayışı doğrultusunda analiz edilmektedir.

\section{Avrupa Birliği’nin Siber Güvenliğe Yönelik Uygulamaları, Politikası ve Hedefleri}

AB'nin siber güvenlik uygulamaları, politikaları ve hedefleri çerçevesinde 2013 yılında Avrupa Komisyonu tarafindan yayımlanan “Avrupa Birliği'nin Siber Güvenlik Stratejisi” belgesi, bu alandaki ilk somut adımı teşkil etmesi nedeniyle son derece önemli bir mihenk taşını oluşturmaktadır. $\mathrm{Bu}$ noktada $\mathrm{AB}$ 'nin siber güvenlik politikaları, söz konusu belgeden önce ve sonra atılan adımlar ekseninde ele alınmalıdır. Bu minvalden hareketle, öncelikle 2013 yılında yayımlanan

${ }^{22}$ Marise Cremona, "Coherence through Law: What Difference will the Treaty of Lisbon Make?", Hamburg Review of Social Sciences, 2008, Vol 3, No 1, pp. 11-36; Karolina Pomorska and Sophie Vanhoonacker, "Europe as a Global Actor: Searching for a New Strategic Approach", JCMS, 2016, Vol 52, No 1, pp. 216-229.

${ }^{23}$ European Commission ${ }_{\mathrm{a}}$, "Some Practical Proposals for Greater Coherence, Effectiveness and Visibility", 2006, https://ec.europa.eu/councils/bx20060615/ euw_com06_278_en.pdf, (Erişim Tarihi: 03.04.2020).

24 Antonio Missiroli, "Towards $\mathrm{An} \mathrm{Eu}$ Global Strategy: Background, Process, References", 2015, https://www.iss.europa.eu/sites/default/files/EUISSFiles/Towards_ an_EU_Global_Strategy_0_0.pdf, (Erişim Tarihi: 12.03.2020). 
Avrupa Birliği’nin Siber Güvenlik Politikası:

Kurumsalcılık mı Tutarlılık mı?

siber güvenlik strateji belgesi öncesindeki dönem analiz edilmektedir.

AB'nin siber güvenlik politikasının ilk izlerinin başlangıç noktası, 1985 yılında Avrupa Komisyonu tarafindan ortaya konan "Tek Pazar İnisiyatifine" uzanmaktadır. Nitekim 1985 yılında Avrupa Komisyonu'nun hazırladığı Beyaz Kitap'ta, bilgi teknolojileri ve telekomünikasyon sektörüne yönelik özel bir ilginin başladığ1 görülmektedir. ${ }^{25}$ Ayrıca, yeni bilgi teknolojilerinin kullanımının ekonomik büyümeye neden olacağı vurgulanmaktadır. ${ }^{26}$ AB'nin siber politikasının gelişiminde önem arz eden bir diğer belge, 1994 yılında kabul edilen "Bangemann Raporu'dur". Nitekim söz konusu rapor doğrultusunda, $A B$ 'nin siber güvenlik politikası daha görünür bir hale gelmekte ve aktörler arası iş birliğinin güçlendirilmesinin, fikri mülkiyet haklarının korunmasının, internet korsancılığıyla mücadelenin ve AB'nin sosyo-ekonomik gelişiminde bilgi ve iletişim teknolojilerinin önemine yapılan atıflar dikkati çekmektedir. ${ }^{27}$ Öte yandan, odak noktası gerçek kişiler olan ve verilerin işlenmesi sırasında kişi hak ve özgürlüklerinin korunmasını içeren 25 Kasım 1995 tarihli "Verilerin Korunması Direktifi"; ${ }^{28}$ ulusal güvenlik, ekonomik güvenlik, bilgi güvenliği, fikri mülkiyet, özel yaşamın korunması gibi unsurları içeren 16 Ekim 1996 tarihli "İnternetin Yasal Olmayan ve Zararlı İçeriğine İlişkin Belge"; ${ }^{29}$ siber uzaydan kaynaklanan tehditlerin ilk kez detaylı

\footnotetext{
${ }^{25}$ European Commission, “Completing the Internal Market”, 1985, p. 20, https://eurlex.europa.eu/legal-content/EN/TXT/PDF/?uri=CELEX:51985DC0310\&from=EN, (Erişim Tarihi: 09.02.2020).

${ }^{26}$ Ibid., p. 31.

27 European Council, "European Council Conclusions Corfu", 1994, http://aei.pitt.edu/1444/1/corfu_june_1994.pdf, (Erişim Tarihi: 09.03.2020); Martin Bangemann, "Recommendations to the European Council Europe and the Global Information Society", 1994, http://www.channelingreality.com/Digital_Treason/ Brussels_1995/Bangemann_report.pdf, (Erişim Tarihi: 13.03.2020).

${ }^{28}$ European Parliament and Council, "Directive on the Protection of Individuals with Regard to the Processing of Personal Data and on the Free Movement of Such Data", 1995, https://eur-lex.europa.eu/legal-content/EN/TXT/?uri=CELEX\%3A31995L0046, (Erişim Tarihi: 10.03.2020).

${ }_{29}$ European Commission, "Illegal and Harmful Content on Internet", 1996, p. 3,
}

\section{5}

Güvenlik Stratejileri

Cilt: 16

Say1: 35 
646

Güvenlik

Stratejileri

Cilt: 16

Sayı: 35

bir tipolojisini içeren, ${ }^{30}$ güvenliğin güçlendirilmesine ilişkin somut teknik önlemleri ortaya koyan, ${ }^{31}$ ilk kez ağ ve bilgi güvenliğini ${ }^{32}$ tanımlayan, siber güvenlik çerçevesinde aktörler arası iş birliğini vurgulayan $^{33} 2001$ yılındaki A $\breve{g}$ ve Bilgi Güvenliğine İlişkin Öneri (NIS Proposal); gerçek kişilerle beraber tüzel kişileri de içeren 31 Temmuz 2002 tarihli "Elektronik Haberleşme Sektöründe Gizliliğin Korunmas1 Direktifi"; ${ }^{34}$ siber saldırı durumunda koordinasyon sorumluluğu bulunan, ulusal siber güvenlik stratejilerini koordine eden, üye devletlere, $\mathrm{AB}$ kurumlarına ve özel sektöre bilgi ve uzmanlık sağlayan, ağ ve bilgi güvenliğiyle ilişkili (NIS) AB politikalarının uygulanması ve gelişmesini yönlendiren ENISA'nın bir tüzel kişilik olarak 13 Mart 2004 'de kurulması ${ }^{35}$ AB ekseninde gerçekleştirilen siber saldırılara yönelik cezai yaptırımların artırılması için üye devletlerle iş birliğini hedefleyen 23 Şubat 2005 tarihli "Bilgi Sistemlerine Saldırılar Hakkında AB Konseyi Çerçeve Kararı ${ }^{36}$ suçların tespiti ve soruşturulması için üye devletlerin yasal mevzuatlarında tanımlanan telefon ve e-posta

http://aei.pitt.edu/5895/1/5895.pdf, (Erişim Tarihi: 10.03.2020).

30 European Commission, "Network and Information Security: Proposal for A European Policy Approach", 2001, pp. 9-15, https://ec.europa.eu/transparency/regdoc/ rep/1/2001/EN/1-2001-298-EN-F1-1.Pdf, (Erişim Tarihi: 11.03.2020).

31 Ibid., pp. 20-25.

${ }^{32}$ A ̆ ve bilgi güvenliği; bir ağın veya bir bilgi sisteminin, depolanan veya iletilen verilerin ve bu ağlar tarafından sunulan veya bunlara erişilebilen ilgili hizmetlerin kullanılabilirliğini, özgünlügünü, bütünlügünü ve gizliliğini tehlikeye atan olaylara veya kötü amaçlı eylemlere karşı direnme yeteneği ve sistemleri olarak tanımlanmaktadır. Ibid., p. 9.

${ }^{33}$ Ibid., pp. 26-27.

${ }^{34}$ European Parliament and Council, "Directive on the Concerning the Processing of Personal Data and the Protection of Privacy in the Electronic Communications Sector", 2002, https://eur-lex.europa.eu/legal-content/EN/TXT/PDF/?uri=CELEX:32002L0058 \&from=EN, (Erişim Tarihi: 11.03.2020).

35 ENISA, "About ENISA", 2020, https://www.enisa.europa.eu/about-enisa, (Erişim Tarihi: 12.04.2020).

${ }^{36}$ European Council, "Council Framework Decision on Attacks against Information Systems", 2005, https://eur-lex.europa.eu/legal-content/EN/TXT/PDF/?uri=CELEX: 32005F0222\&from=EN, (Erişim Tarihi: 11.03.2020). 
Avrupa Birliği’nin Siber Güvenlik Politikası:

Kurumsalcılık mı Tutarlılık mı?

verilerinin saklanmas1 sorumluluğunu getiren 15 Mart 2006 tarihli "Verilerin Saklanması Direktifi"; ${ }^{37}$ ve ağ ve bilgi güvenliği politikasını canlandırma hedefi doğrultusunda kabul edilen 31 Mayıs 2006 tarihli "Güvenli Bilgi Toplumu İçin Strateji” belgesi ${ }^{38}$ (European Commission, 2006) $A B$ 'nin siber güvenlik politikasının gelişiminde rol oynayan önemli mihenk taşlarıdır. Ayrıca, 2012 yılında AB Bilgisayar Acil Müdahale Ekibi'nin (CERT-EU) ve 2013 yılında siber suçlara ilişkin sınır ötesi faaliyetleri koordine eden, bu alanda teknik uzmanlık sağlayan ve yetkileri peyderpey arttırilan Avrupa Siber Suç Merkezi'nin (European Cybercrime Centre-EC3) kurulmas1 AB'nin siber güvenlik politikası bağlamında önem arz etmektedir.

AB'nin siber güvenlik politikasının somut bir zemine oturmas1 bağlamında ise 7 Şubat 2013 tarihinde Avrupa Komisyonu tarafindan yayımlanan "Siber Güvenlik Strateji Belgesi" büyük bir rol oynamaktadır. Söz konusu belge çerçevesinde beş önemli hususa odaklanılmaktadır: siber direncin güçlendirilmesi, siber suçların azaltılması, ortak güvenlik ve savunma politikası (OGSP) doğrultusunda siber savunma politikasının ve kapasitesinin geliştirilmesi, $\mathrm{AB}$ için tutarlı bir uluslararası siber güvenlik politikasının oluşturulması, $\mathrm{AB}$ temel değerlerinin teşvik edilmesi ve siber güvenlik için endüstriyel ve teknolojik kaynakların geliştirilmesi. $^{39} 2013$ yılındaki strateji belgesi sonrasında AB, siber alanda politikalarını güçlendirmeye devam etmektedir. Bu bağlamda, 2015 y1lında siber suçlarla mücadeleyi ön plana alan "Güvenlik Üzerine

\footnotetext{
${ }^{37}$ European Parliament and Council, "Directive on the Retention of Data Generated or Processed in Connection with the Provision of Publicly Available Electronic Communications Services or of Public Communications Networks and Amending", 2006, https://eur-lex.europa.eu/legal-content/EN/TXT/PDF/?uri=CELEX:32006L0024 \& from=GA, (Erişim Tarihi: 11.03.2020).

38 European Commission $_{\mathrm{b}}$, "Strategy for a Secure Information Society", 2006, https://eur-lex.europa.eu/legal-content/EN/TXT/HTML/?uri=LEGISSUM:124153a, (Erişim Tarihi: 03.04.2020).

${ }^{39}$ European Commission, "Cybersecurity Strategy of the European Union: An Open, Safe and Secure Cyberspace", 2013, pp. 4-5, http://eeas.europa.eu/archives/docs/ policies/eu-cyber-security/cybsec_comm_en.pdf, (Erişim Tarihi: 15.03.2020).
}

\section{7}

Güvenlik Stratejileri

Cilt: 16

Say1: 35 
648

Güvenlik Stratejileri

Cilt: 16

Say1: 35

Avrupa Gündemi” ve malların, kişilerin, hizmetlerin, sermayenin serbest dolaşımının sağlandığı; bireylerin, işletmelerin adil rekabet ve verilerin korunması koşulu altında çevrimiçi faaliyetlere sorunsuz bir şekilde erişebildiği ve dijital ekonominin güçlendirilmesi odaklı "Dijital Tek Pazar'a" ilişkin strateji kabul edilmiştir. ${ }^{40}$ Öte yandan, ağ ve bilgi sistemlerinin güvenliğini artırmayı, siber güvenlik alanında üye devletler arasında iş birliğini güçlendirmeyi amaçlayan ve ilk yasal düzenleme olan NIS Direktifi 6 Temmuz 2016 tarihinde Avrupa Parlamentosu'nda kabul edilip, Ağustos 2016'da yürürlüğe girmiştir. ${ }^{41}$ AB'nin siber güvenlik politikasının güçlendirilmesine ilişkin bir diğer adım 2013 yılında yayımlanan siber güvenlik strateji belgesinin 2017 yılında revize edilmesi iken ${ }^{42}$ bu alanın yasal boyuta taşınması bağlamında son derece önemli olan bir diğer adım ise 2017 yılından itibaren üzerinde çalışlan ve 11 Mart 2019 tarihinde Avrupa Parlamentosu'nda onaylanıp, 27 Haziran 2019'da yürürlüğe giren 'Siber Güvenlik Yasası'dır". Söz konusu yasa çerçevesinde temel olarak iki hedefe odaklanılmaktadır: i) siber güvenlik tehditleri ve saldırılarıyla mücadelede üye devletleri desteklemek konusunda ENISA'nın yetkilerinin güçlendirilmesi ve daimi bir $\mathrm{AB}$ siber güvenlik ajansına dönüşmesi, ii) bilgi ve iletişim teknolojileri bağlamında tüm üye devletlerde geçerli olacak siber güvenlik sertifikasının oluşturulması. ${ }^{43}$ Bu bağlamda AB Siber Güvenlik Yasası, dijital ortamın güvenliğini artırmayı amaçlayan Avrupa Birliği'nin

${ }^{40}$ European Commission $_{\mathrm{a}}$, "The European Agenda on Security", 2015, https://eurlex.europa.eu/legal-content/GA/TXT/?uri=CELEX:52015DC0185, (Erişim Tarihi: 17.03.2020); European Commission 2015, https://eur-lex.europa.eu/legal-content/EN/TXT/?uri=celex\%3A52015DC0192, (Erişim Tarihi: 18.03.2020).

${ }^{41}$ European Commission, "The Directive on Security of Network and Information Systems (NIS Directive)", 2020, https://ec.europa.eu/digital-single-market/en/networkand-information-security-nis-directive, (Erişim Tarihi: 17.03.2020).

${ }^{42}$ European Commission $_{\mathrm{a}}$, "Resillience, Detterence and Defence: Building Strong Cyber Secuirty for the EU", 2017, https://eur-lex.europa.eu/legalcontent/en/TXT/?uri=CELEX\%3A52017JC0450, (Erişim Tarihi: 14.04.2020).

${ }^{43}$ European Commission ${ }_{\text {b }}$, "Cyber Security Act", 2017, https://eur-lex.europa.eu/legal-content/ EN/TXT/HTML/?uri=CELEX:52017PC0477\&from=EN, (Erişim Tarihi: 19.04.2020). 
Avrupa Birliği’nin Siber Güvenlik Politikası:

Kurumsalcılık mı Tutarlılık mı?

genel siber politikasının önemli bir parçasıdır.

Tarihsel bir kronoloji ekseninde AB'nin siber güvenlik politikasının gelişimi doğrultusunda sosyo-ekonomik merkezli bir yaklaşım ön plandadır. Nitekim Avrupa Komisyonu'nun hazırladığg ve 1 Ocak 1993'e kadar tek pazar oluşturulması hedefini ortaya koyan 1985 yılındaki Beyaz Kitap, "iç pazar/tek pazar" terimini kurucu antlaşmaya dâhil eden ve 1 Temmuz 1987 tarihinde yürürlüğge giren Avrupa Tek Senedi (ATS), 1 Kasım 1993'de yürürlüğe girerek, Avrupa Birliğini kuran Maastricht Antlaşması ${ }^{44}$ (AB Antlaşması-ABA) ile bu hususun daha belirgin hale geldiği görülmektedir. ${ }^{45}$ Öte yandan, 1994 yılında yayımlanan Bangemann Raporu; istihdamın yaratılmas1, piyasa güçleri, fayda maksimizasyonu ve sosyal değişim gibi sosyoekonomik unsurların altını çizmekte ve bu unsurlar çerçevesinde politikalar belirlenmesi gerekliliğini vurgulamaktadır. ${ }^{46}$ Bununla beraber, 1995 yılında yayımlanan "Verilerin Korunmas1 Direktifi", ekonomik ve sosyal refahın güçlendirilmesi gerekliliğine vurgu yaparken 1996 y1lında yayımlanan "Internetin Yasal Olmayan ve Zararlı İçeriğine İlişkin Belge" ise büyüyen internet ekonomisi doğrultusunda ekonomik güvenliğe, internetin, ekonomik gelişimi güçlendirmesine, iç pazara yönelik yasal çerçeveye, rekabet kuralları doğrultusunda ağ ve bilgi sistemlerine ilişkin güvenliğin sağlanmasına odaklanmaktadır. Ayrıca söz konusu belgede internetin sosyal, kültürel ve eğitimsel alanlardaki güçlü etkisinin altı çizilmektedir. ${ }^{47}$ Diğer

\footnotetext{
44 ATS, güvenlik konseptinin ilk kez dile getirildiği ancak güvenliğe yönelik daha sembolik bir önemin vurgulandığı bir belge iken ABA ise ortaya koyduğu üç sütunlu yapıdan biri olan ve hükümetlerarası özellik taşıyan ortak dış ve güvenlik politikası çerçevesinde güvenlik konusunu daha somut bir zeminde ele almaktadır.

45 European Commission, "Completing the Internal Market"; Single European Act, 1987, https://eur-lex.europa.eu/legal-content/EN/TXT/PDF/?uri=CELEX:11986U/ TXT\&from=EN, (Erişim Tarihi: 10.03.2020); Maastricht Treaty, 1992, https://europa.eu/european-union/sites/europaeu/files/docs/body/treaty_on_european_ union_en.pdf, (Erişim Tarihi: 21.03.2020).

${ }^{46}$ European Council, "Conclusions Corfu"; Bangemann, "Global Information Society".

${ }^{47}$ European Commission, "Illegal and Harmful", p. 3, 5, 7, 19.
}

\section{9}

Güvenlik Stratejileri

Cilt: 16

Say1: 35 
650

Güvenlik Stratejileri

Cilt: 16

Say1: 35

taraftan, 2001 y1lındaki "NIS Önerisinde" ekonomik ve sosyal kalkınmada ağ ve bilgi sistemlerinin temel bir unsur olduğu belirtilmektedir. ${ }^{48} 2002$ tarihli "Elektronik ve Haberleşme Sektöründe Gizliliğin Korunması Direktifinde" ise devletlerin ekonomik refahının sağlanması (md.11), piyasanın gelişimi (md.4), internetin pazar yapısını bozmamasına (md.6) ve pazar yapısını bozabilecek dijital sistemlere yönelik önlemlere (md.8) ilişkin atıflar bulunduğu görülürken ${ }^{49} 2006$ tarihli " Güvenli Bilgi Toplumu İçin Strateji” belgesinde, Avrupa ekonomisi ve bir bütün olarak Avrupa toplumu için bilgi ve iletişim teknolojileri kaynaklı risklerin ciddiye alınması, ekonominin canlanması çerçevesinde büyüme ve istihdama yönelik bir “Avrupa Güvenlik Toplumu'nun” tesis edilmesi gerekliliği üzerinde durulmaktadır. ${ }^{50} 2013$ yılında yayımlanan "Siber Güvenlik Strateji" belgesinde ise bilgi ve iletişim teknolojilerinin sosyal etkileşim ve ekonomik büyüme için önemli bir belkemiği haline dönüştüğü ve finans, sağlık, enerji, ulaştırma gibi kilit sektörlerde önem arz ettiği ortaya konmaktadır. ${ }^{11}$ Öte yandan, 2015 yilındaki "Dijital Tek Pazar Stratejisi'nde" küresel ekonominin büyük bir hızla dijitalleștiği, dijital ekonominin Avrupa pazarını güçlendiren yeni kaynaklar ve istihdam yaratan bir unsur olduğu, bilgi ve iletişim teknolojilerinin ekonomik ve sosyal yapıyı etkilediği ortaya konarken ${ }^{52} 2016$ y1lında kabul edilen "NIS Direktifi'nde ise enerji, ulaşım, bankacılık, sağlık, finans ve dijital altyapı gibi sektörlerin bilgi ve iletişim teknolojisine dayanması bağlamında ekonomik ve sosyal yapının güvenliğinin sağlanmasının altı çizilmektedir. ${ }^{53}$ Bununla beraber, 2013 yılındaki siber güvenlik strateji belgesinin 2017 yılında revize edilmiş versiyonunda

${ }^{48}$ European Commission, "Network and Information", p. 2, 16.

${ }^{49}$ European Parliament and Council, "Personal Data".

${ }^{50}$ European Commission, "Strategy for a Secure".

${ }^{51}$ European Commission, "Cybersecuriy Strategy", p. 2.

${ }^{52}$ European Commission, "A Digital Single".

${ }^{53}$ European Parliament and Council, "Directive on Network and Information Systems across the Union", 2016, https://eur-lex.europa.eu/legal-content/EN/TXT/?uri=uriserv: OJ.L_.2016.194.01.0001.01.ENG\&toc=OJ:L:2016:194:TOC, (Erişim Tarihi: 15.04.2020). 
Avrupa Birliği’nin Siber Güvenlik Politikası:

Kurumsalcılık mı Tutarlılık mı?

ekonominin, dijital teknolojiye bağımlı olduğu ve siber güvenliğin sağlanmasında ekonomik ve sosyal yapı odaklı önlemler alınması gerekliliği ele alınırken ${ }^{54} 2019$ yılında yürürlüğe giren "Siber Güvenlik Yasası", diğer belgelerde olduğu gibi bir kez daha ağ ve bilgi sistemlerinin ekonomik büyüme ve sosyal refahın temeli olduğunu vurgulamaktadır. ${ }^{55}$ Son kertede, analiz edilen tüm bu belgeler çerçevesinde AB'nin bilgi ve iletişim teknolojilerine yönelik yaklaşımı ve dolayısıyla siber güvenlik politikasının sosyo-ekonomik merkezli olduğu sonucuna ulaşılmaktadır.

Öte yandan, siber güvenliğe yönelik ilk izlerin görülmeye başlandığı 1985 yılından günümüze Birlik, beş temel hedef çerçevesinde siber güvenlik politikasını geliştirmeye yönelmektedir. Söz konusu bu beş temel hedef ise ekonomik fayda/maksimizasyonun sağlanması, temel hakların korunması, siber suçları/saldırıların önlenmesi, dijital sisteme yönelik güven unsurunun artırılması ve aktörler arasında iş birliğinin güçlendirilmesidir. Mevzubahis beş hedefe, çalışma boyunca incelenen dokümanların içerik analizine tabi tutulması çerçevesinde ulaşılmıştır. Elde edilen veriler ise şu şekildedir:

\footnotetext{
${ }^{54}$ European Commission, "Resillience".

${ }^{55}$ European Commission, "Regulation on ENISA and on Information and Communications Technology Cybersecurity Certification and Repealing Regulation (Cybersecurity Act)", 2019, https://eur-lex.europa.eu/legal-content/EN/TXT/PDF /?uri=CELEX:32019R0881\&from=EN, (Erişim Tarihi:01.05.2020).
}

\section{1}

Güvenlik Stratejileri

Cilt: 16

Say1: 35 
652

Güvenlik Stratejileri

Cilt: 16

Sayı: 35

Tablo 1 $1_{\mathrm{a}}$ : 2013 Strateji Belgesi Öncesi Ekonomik Unsur ${ }^{56}$

\begin{tabular}{|c|c|c|c|c|c|c|}
\hline $\begin{array}{c}1985 \\
\text { İç Pazarın } \\
\text { Tamamlanmasına } \\
\text { İlişkin İnisiyatif }\end{array}$ & $\begin{array}{c}1994 \\
\text { Bangemann } \\
\text { Raporu }\end{array}$ & $\begin{array}{c}1995 \\
\text { Verilerin } \\
\text { Korunması } \\
\text { Direktifi }\end{array}$ & $\begin{array}{c}1996 \\
\text { İnternetin } \\
\text { Yasal } \\
\text { Olmayan } \\
\text { Zararlı } \\
\text { İçeriğine } \\
\text { İlişkin Belge }\end{array}$ & $\begin{array}{c}2001 \\
\text { NIS } \\
\text { Önerisi }\end{array}$ & $\begin{array}{c}2002 \\
\text { Gizliliğin } \\
\text { Korunması } \\
\text { Direktifi }\end{array}$ & $\begin{array}{c}2006 \\
\text { Güvenli } \\
\text { Bilgi } \\
\text { Toplumu } \\
\text { İçin } \\
\text { Strateji }\end{array}$ \\
\hline $\begin{array}{c}\text { Yeni bilgi } \\
\text { teknolojileri, } \\
\text { ekonomik } \\
\text { büyümeye neden } \\
\text { olacaktır. }^{57}\end{array}$ & $\begin{array}{c}\text { Bilgi toplumu, } \\
\text { Avrupa } \\
\text { vatandaşlarının } \\
\text { yaşam } \\
\text { kalitesini } \\
\text { iyileştirme, } \\
\text { sosyal ve } \\
\text { ekonomik } \\
\text { kalkınmayı } \\
\text { güçlendirme } \\
\text { ve uyumu } \\
\text { artırma } \\
\text { potansiyeline } \\
\text { sahiptir. } \\
\text { s8 }\end{array}$ & $\begin{array}{c}\text { Ekonomik } \\
\text { kalkınma } \\
\text { ve refahın } \\
\text { sağlanması } \\
\text { gerekmektedir. }\end{array}$ & $\begin{array}{c}\text { İnternet } \\
\text { ekonomisi, bir } \\
\text { dizi ekonomik } \\
\text { sektörü kökten } \\
\text { etkilemektedir. } \\
\text { Aynı zamanda } \\
\text { internet; } \\
\text { sosyal, } \\
\text { eğitimsel ve } \\
\text { kültürel } \\
\text { alanlarda da } \\
\text { güçlü bir } \\
\text { etkiye } \\
\text { sahiptir. } \\
\end{array}$ & $\begin{array}{l}\text { Bilgi ve } \\
\text { iletişim } \\
\text { güvenliği, } \\
\text { ekonominin } \\
\text { gelişiminde } \\
\text { temel bir } \\
\text { unsurdur. }^{60}\end{array}$ & $\begin{array}{c}\text { Internet, } \\
\text { geleneksel } \\
\text { pazar yapısını } \\
\text { bozmamalıdır. }\end{array}$ & $\begin{array}{c}\text { Avrupa } \\
\text { ekonomisi } \\
\text { bilgi ve } \\
\text { iletişim } \\
\text { teknolojileri } \\
\text { kaynaklı } \\
\text { riskleri } \\
\text { ciddiye } \\
\text { almalıdır. }\end{array}$ \\
\hline
\end{tabular}

Tablo $1_{b}$ : 2013 Strateji Belgesi ve Sonrası Ekonomik Unsur

\begin{tabular}{|c|c|c|c|c|}
\hline $\begin{array}{c}2013 \text { Siber Güvenlik } \\
\text { Strateji Belgesi }\end{array}$ & $\begin{array}{c}\text { 2015 Dijital } \\
\text { Tek Pazar Stratejisi }\end{array}$ & $\begin{array}{c}\mathbf{2 0 1 6} \\
\text { NIS Direktifi }\end{array}$ & $\begin{array}{c}\text { 2017 Revize Edilmiş } \\
\text { Siber Güvenlik } \\
\text { Strateji Belgesi }\end{array}$ & $\begin{array}{c}\text { So19 } \\
\text { Siber Güvenlik } \\
\text { Yasası }\end{array}$ \\
\hline $\begin{array}{c}\text { BIT ekonomik } \\
\text { büyümenin } \\
\text { belkemiğidir. }\end{array}$ & $\begin{array}{c}\text { Avrupa dijital } \\
\text { ekonomisinin } \\
\text { maksimize edilmesi } \\
\text { temel hedeflerden } \\
\text { biridir. }\end{array}$ & $\begin{array}{c}\text { Iç pazar bağlamında } \\
\text { BIT güvenliğinin } \\
\text { sağlanması } \\
\text { gerekmektedir } \\
\text { (md.1). }\end{array}$ & $\begin{array}{c}\text { Ekonomik gelişim } \\
\text { büyük oranda dijital } \\
\text { teknolojilere } \\
\text { bağımlidır. }\end{array}$ & $\begin{array}{c}\text { BIT ekonomik } \\
\text { büyümeyi } \\
\text { desteklemektedir } \\
\text { (md.2). }\end{array}$ \\
\hline
\end{tabular}

${ }^{56}$ Tablo 1-5 arası yazarın kendisi tarafindan oluşturulmuştur.

${ }^{57}$ European Commission, "Completing the Internal Market", p. 31.

${ }^{58}$ Bangemann, "Global Information Society", p. 11.

${ }^{59}$ European Commission, "Illegal and Harmful", p. 3.

${ }^{60}$ European Commission, "Network and Information", p. 18.

${ }^{61}$ European Commission, "Cybersecurity Strategy", p. 2. 
Avrupa Birliği’nin Siber Güvenlik Politikası:

Kurumsalc1lık mı Tutarlılık mı?

Tablo 2a 2013 Strateji Belgesi Öncesi Güven Unsuru

\begin{tabular}{|c|c|c|c|c|}
\hline $\begin{array}{c}1994 \\
\text { Bangemann } \\
\text { Raporu }\end{array}$ & $\begin{array}{c}1995 \\
\text { Verilerin } \\
\text { Korunması } \\
\text { Direktifi }\end{array}$ & $\begin{array}{c}1996 \\
\text { İnternetin Yasal } \\
\text { Olmayan Zararlı } \\
\text { İçeriğine İlişkin } \\
\text { Belge }\end{array}$ & $\begin{array}{c}2001 \\
\text { NIS Önerisi }\end{array}$ & $\begin{array}{c}2002 \\
\text { Gizliliğin } \\
\text { Korunması } \\
\text { Direktifi }\end{array}$ \\
\hline $\begin{array}{l}\text { Yeni teknolojilerin } \\
\text { kullanımını } \\
\text { sağlamak için } \\
\text { toplumda bunların } \\
\text { güvenliğine ilişkin } \\
\text { genel bir kabulün } \\
\text { sağlanmasında çaba } \\
\text { sarf edilmelidir. }^{2}\end{array}$ & $\begin{array}{l}\text { BIT'ne yönelik } \\
\text { güven artırıcı } \\
\text { önlemler alınması } \\
\text { gerekmektedir. }\end{array}$ & $\begin{array}{l}\text { Üye devletler } \\
\text { dijital sistemlere } \\
\text { ilişkin güven } \\
\text { artırıcı önlemleri } \\
\text { takip etmelidir. }\end{array}$ & $\begin{array}{c}\text { Güvenlik } \\
\text { tehditlerinden } \\
\text { endişe duyan } \\
\text { birçok kullanıcının } \\
\text { e-ticaretten } \\
\text { kaçınma riski } \\
\text { vardır Dijital } \\
\text { sistemlere yönelik } \\
\text { güvenin } \\
\text { güçlendirilmesi } \\
\text { gerekmektedir. }\end{array}$ & $\begin{array}{c}\text { Dijital } \\
\text { sistemlere karş1 } \\
\text { güven artırıcı } \\
\text { önlemler } \\
\text { alınmalıdır } \\
\text { (md.20). }\end{array}$ \\
\hline
\end{tabular}

\section{3}

Güvenlik Stratejileri

Cilt: 16

Say1: 35

Tablo 2 2013 Strateji Belgesi ve Sonrası Güven Unsuru

\begin{tabular}{|c|c|c|c|c|}
\hline $\begin{array}{c}2013 \\
\text { Siber Güvenlik } \\
\text { Strateji Belgesi }\end{array}$ & $\begin{array}{c}2015 \\
\text { Dijital Tek Pazar } \\
\text { Stratejisi }\end{array}$ & $\begin{array}{c}2016 \\
\text { NIS Direktifi }\end{array}$ & $\begin{array}{c}2017 \text { Revize Edilmiş } \\
\text { Siber Güvenlik } \\
\text { Strateji Belgesi }\end{array}$ & $\begin{array}{c}2019 \\
\text { Siber Güvenlik } \\
\text { Yasası }\end{array}$ \\
\hline $\begin{array}{c}\text { Yeni teknolojilerle } \\
\text { bağlanmak } \\
\text { konusunda } \\
\text { vatandaşların } \\
\text { güvene ihtiyacı } \\
\text { vardır. AB } \\
\text { genelinde her } 10 \\
\text { internet } \\
\text { kullanıcısından biri } \\
\text { siber saldırı } \\
\text { kurbanıdır. }\end{array}$ & $\begin{array}{l}\text { Dijital risklere } \\
\text { yönelik güvenin } \\
\text { artırılması gelecek } \\
\text { jenerasyon için } \\
\text { önemlidir. }\end{array}$ & $\begin{array}{l}\text { Güvenli servis } \\
\text { sağlayıcıları için } \\
\text { gereken adımlar } \\
\text { atılmalıdır } \\
\text { (md.7). }\end{array}$ & $\begin{array}{l}\text { Gelişen teknolojilere } \\
\text { yönelik güven tesis } \\
\text { edilmelidir. } \\
\text { Tüketiciler, yeni } \\
\text { teknolojilere güvendiği } \\
\text { için zarar görmektedir. }\end{array}$ & $\begin{array}{l}\text { Sertifika kullanımı, } \\
\text { dijital sistemlere } \\
\text { güven artmasına yol } \\
\text { açacaktır. BIT } \\
\text { bağlamında güven } \\
\text { tesis edilmelidir } \\
\text { (md.4,7). }\end{array}$ \\
\hline
\end{tabular}

${ }^{62}$ Bangemann, “Global Information Society", p.12.

${ }^{63}$ European Commission, "Illegal and Harmful", pp. 15-16.

${ }^{64}$ European Commission, "Network and Information", p. 10, 15, 20-21.

${ }^{65}$ European Commission, "Cybersecurity Strategy", pp. 2-3. 
654

Güvenlik Stratejileri

Cilt: 16

Sayı: 35

Tablo $3_{\mathrm{a}}$ : 2013 Strateji Belgesi Öncesi Temel Haklar Unsuru

\begin{tabular}{|c|c|c|c|c|c|}
\hline $\begin{array}{c}1995 \\
\text { Verilerin } \\
\text { Korunması } \\
\text { Direktifi }\end{array}$ & $\begin{array}{c}1996 \\
\text { İnternetin Yasal } \\
\text { Olmayan Zararlı } \\
\text { İçeriğine İlişkin } \\
\text { Belge }\end{array}$ & $\begin{array}{c}2001 \\
\text { NIS Önerisi }\end{array}$ & $\begin{array}{c}2002 \\
\text { Gizliliğin } \\
\text { Korunması } \\
\text { Direktifi }\end{array}$ & $\begin{array}{c}2005 \\
\text { Dijital } \\
\text { Sistemler } \\
\text { AB Konsey } \\
\text { Çerçeve Kararı }\end{array}$ & $\begin{array}{c}2006 \\
\text { Verilerin } \\
\text { Saklanması } \\
\text { Direktifi }\end{array}$ \\
\hline $\begin{array}{l}\text { Temel hak ve } \\
\text { özgürlükler } \\
\text { korunmalı ve } \\
\text { sayg1 } \\
\text { gösterilmeli. }\end{array}$ & $\begin{array}{l}\text { İfade ve düşünce } \\
\text { özgürlüğüyle } \\
\text { beraber bir bütün } \\
\text { olarak kişi } \\
\text { haklarının } \\
\text { korunmas1 } \\
\text { gerekmektedir. }^{66}\end{array}$ & $\begin{array}{l}\text { Dijital dünyadan } \\
\text { kaynaklanan } \\
\text { tehditlere karşı } \\
\text { bireysel hakların } \\
\text { korunması temel } \\
\text { önceliktir. }\end{array}$ & $\begin{array}{c}\text { Bireysel hak } \\
\text { ve özgürlükler } \\
\text { garanti altına } \\
\text { alınmalıdır } \\
\text { (md.1,2,3). }\end{array}$ & $\begin{array}{l}\text { Temel haklara } \\
\text { sayg1 } \\
\text { gösterilmelidir } \\
\text { (md.18) }\end{array}$ & $\begin{array}{l}\text { Bireysel hak ve } \\
\text { özgürlükler } \\
\text { korunmalı ve } \\
\text { buna yönelik } \\
\text { yasal önlemler } \\
\text { alınmalıdır } \\
\text { (md.1,9,17). }\end{array}$ \\
\hline
\end{tabular}

\section{Tablo 3 $3_{b}$ : 2013 Strateji Belgesi ve Sonrası} Temel Haklar Unsuru

\begin{tabular}{|c|c|c|c|c|}
\hline $\begin{array}{c}2013 \\
\text { Siber Güvenlik } \\
\text { Strateji Belgesi }\end{array}$ & $\begin{array}{c}2015 \\
\text { Dijital Tek Pazar } \\
\text { Stratejisi }\end{array}$ & $\begin{array}{c}2016 \\
\text { NIS Direktifi }\end{array}$ & $\begin{array}{c}2017 \text { Revize } \\
\text { Edilmiş Siber } \\
\text { Güvenlik Strateji } \\
\text { Belgesi }\end{array}$ & $\begin{array}{c}2019 \\
\text { Siber Güvenlik } \\
\text { Yasası }\end{array}$ \\
\hline $\begin{array}{l}\text { Bilgiye erişim ve ifade } \\
\text { özgürlüğü dâhil olmak } \\
\text { üzere temel hakların } \\
\text { teşvik edilmesi ve } \\
\text { korunası } \\
\text { gerekmektedir. }^{68}\end{array}$ & $\begin{array}{c}\text { Siber tehditler } \\
\text { vatandaşların temel } \\
\text { hakarına sorun teşkil } \\
\text { etmektedir. Görsel- } \\
\text { işitsel sektördeki } \\
\text { haklara saygı } \\
\text { gösterilmesi, fikri } \\
\text { mülkiyet haklarının, } \\
\text { tüketicilerin gizlilik ve } \\
\text { kişisel verilerin } \\
\text { korunması önemlidir. }\end{array}$ & $\begin{array}{l}\text { Temel haklara saygı } \\
\text { gösterilmesi, } \\
\text { tüketici ve firmaları } \\
\text { siber tehditlerden } \\
\text { korumak önemlidir } \\
\text { (md.75). }\end{array}$ & $\begin{array}{c}\text { Avrupa'nın refahını, } \\
\text { toplumunu, } \\
\text { değerlerini, hak ve } \\
\text { özgürlüklerini } \\
\text { korurken proaktif } \\
\text { yaklaşım önemlidir. } \\
\text { Dijital tek pazar, } \\
\text { temel hakların } \\
\text { korunmasına } \\
\text { odaklanmıştır. }\end{array}$ & $\begin{array}{l}\text { Fikri mülkiyet } \\
\text { hakları } \\
\text { korunmalıdır. }\end{array}$ \\
\hline
\end{tabular}

${ }^{66}$ European Commission, "Illegal and Harmful", pp. 10-11, 18.

${ }^{67}$ European Commission, "Network and Information", p. 22.

${ }^{68}$ European Commission, "Cybersecurity Strategy", p. 16. 
Avrupa Birliği’nin Siber Güvenlik Politikası:

Kurumsalcılık mı Tutarlılık mı?

Tablo 4 $4_{\mathrm{a}}$ : 2013 Strateji Belgesi Öncesi Siber Saldırıları Önleme Unsuru

\begin{tabular}{|c|c|c|c|c|c|}
\hline $\begin{array}{l}1996 \text { İnternetin } \\
\text { Yasal Olmayan } \\
\text { Zararlı İçeriğine } \\
\text { İlişkin Belge }\end{array}$ & $\begin{array}{c}2001 \\
\text { NIS Önerisi }\end{array}$ & $\begin{array}{c}2002 \\
\text { Gizliliğin } \\
\text { Korunması } \\
\text { Direktifi }\end{array}$ & $\begin{array}{c}2005 \\
\text { Dijital Sistemler } \\
\text { AB Konsey } \\
\text { Çerçeve Kararı }\end{array}$ & $\begin{array}{c}2006 \\
\text { Verilerin } \\
\text { Saklanması } \\
\text { Direktifi }\end{array}$ & $\begin{array}{c}2006 \\
\text { Güvenli Bilgi } \\
\text { Toplumu İçin } \\
\text { Strateji }\end{array}$ \\
\hline $\begin{array}{c}\text { Diğer tüm } \\
\text { iletişim } \\
\text { teknolojileri gibi, } \\
\text { internet } \\
\text { potansiyel olarak } \\
\text { zararlı veya } \\
\text { yasadışı } \\
\text { faaliyetler } \\
\text { bağlamında } \\
\text { kötüye } \\
\text { kullanılabilir. } \\
\text { Siberle bağlantılı } \\
\text { suçlar } \\
\text { önlenmelidir. }{ }^{69}\end{array}$ & $\begin{array}{c}\text { Ağ ve bilgi } \\
\text { güvenliği ile ilgili } \\
\text { önerilen politika } \\
\text { önlemleri sadece } \\
\text { mevcut } \\
\text { telekomünikasyon } \\
\text { ve veri koruma } \\
\text { mevzuatı } \\
\text { bağlamında değil, } \\
\text { aynı zamanda siber } \\
\text { suç politikaları ile } \\
\text { ilgilidir. Siber } \\
\text { tehdit tipolojisi } \\
\text { ekseninde önlemler } \\
\text { alınmalıdır. }\end{array}$ & $\begin{array}{c}\text { İç pazarı } \\
\text { olumsuz } \\
\text { etkileyecek } \\
\text { dijital } \\
\text { kaynaklı } \\
\text { saldırıların } \\
\text { önüne } \\
\text { geçilmelidir } \\
\text { (md.8). }\end{array}$ & $\begin{array}{c}\text { Dijital sistemlere } \\
\text { yönelik } \\
\text { saldırılarla } \\
\text { mücadele } \\
\text { edilmelidir } \\
\text { (md.8). }\end{array}$ & $\begin{array}{c}\text { İç pazarın } \\
\text { bozulmasına } \\
\text { neden olan } \\
\text { dijital } \\
\text { kaynaklı } \\
\text { saldırılar } \\
\text { önlenmelidir } \\
\text { (md.6). }\end{array}$ & $\begin{array}{l}\text { Kolluk kuvvetleri } \\
\text { arasındaki } \\
\text { iş birliğini } \\
\text { iyileştirmek için } \\
\text { önerilerde } \\
\text { bulunmak ve } \\
\text { internetten } \\
\text { yararlanan ve kritik } \\
\text { altyapıların } \\
\text { işleyişini zayıflatan } \\
\text { yeni suç faaliyetleri } \\
\text { ele alınmalıdır. }\end{array}$ \\
\hline
\end{tabular}

\section{5}

Güvenlik Stratejileri

Cilt: 16

Say1: 35

Tablo 4 $4_{b}$ : 2013 Strateji Belgesi ve Sonrası Siber Saldırıları Önleme Unsuru

\begin{tabular}{|c|c|c|c|c|}
\hline $\begin{array}{c}2013 \\
\text { Siber Güvenlik } \\
\text { Strateji Belgesi }\end{array}$ & $\begin{array}{c}2015 \\
\text { Dijital Tek Pazar } \\
\text { Stratejisi }\end{array}$ & $\begin{array}{c}2016 \\
\text { NIS Direktifi }\end{array}$ & $\begin{array}{l}2017 \text { Revize Edilmiş } \\
\text { Siber Güvenlik } \\
\text { Strateji Belgesi }\end{array}$ & $\begin{array}{c}2019 \\
\text { Siber Güvenlik } \\
\text { Yasası }\end{array}$ \\
\hline $\begin{array}{c}\text { AB ekonomisi özel } \\
\text { sektöre ve bireylere } \\
\text { yönelik siber suç } \\
\text { faaliyetlerinden } \\
\text { etkilenmiştir. Siber } \\
\text { alanda ekonomik } \\
\text { casusluk ve devlet } \\
\text { destekli faaliyetlerin } \\
\text { artması, AB } \\
\text { hükümetleri ve } \\
\text { şirketleri için yeni bir } \\
\text { tehdit kategorisi } \\
\text { olussturmaktadır. }\end{array}$ & $\begin{array}{l}\text { Siber tehditlerin } \\
\text { önüne geçilmesine } \\
\text { yönelik politikalar } \\
\text { takip edilmelidir. }\end{array}$ & $\begin{array}{c}\text { BIT'ten } \\
\text { kaynaklanan riskler } \\
\text { önlenmelidir } \\
\text { (md.7). }\end{array}$ & $\begin{array}{c}\text { Üye devletler } \\
\text { tarafindan siber } \\
\text { suçların etkileri } \\
\text { minimize edilmelidir. }\end{array}$ & $\begin{array}{c}\text { Siber saldırı } \\
\text { risklerinin } \\
\text { önlenmesi için } \\
\text { ENISA'nın yetki } \\
\text { ve kapasitesi } \\
\text { artırlımalıdır } \\
\text { (md.16). }\end{array}$ \\
\hline
\end{tabular}

${ }^{69}$ European Commission, "Illegal and Harmful", p. 3.

${ }^{70}$ European Commission, "Network and Information", p. 19.

${ }^{71}$ European Commission, "Strategy for a Secure", p. 5.

${ }^{72}$ European Commission, "Cybersecurity Strategy", p. 3. 
Güvenlik Stratejileri

Cilt: 16

Sayı: 35

Tablo 5 5 $_{\mathrm{a}} 2013$ Strateji Belgesi Öncesi İșbirliği Unsuru

\begin{tabular}{|c|c|c|c|c|}
\hline $\begin{array}{c}1995 \\
\text { Verilerin } \\
\text { Korunması } \\
\text { Direktifi }\end{array}$ & $\begin{array}{c}1996 \\
\text { İnternetin Yasal } \\
\text { Olmayan Zararlı } \\
\text { İçeriğine İlişkin } \\
\text { Belge }\end{array}$ & $\begin{array}{c}2001 \\
\text { NIS Önerisi }\end{array}$ & $\begin{array}{c}2005 \\
\text { Dijital } \\
\text { Sistemler AB } \\
\text { Konsey } \\
\text { Çerçeve } \\
\text { Kararı }\end{array}$ & $\begin{array}{c}2006 \\
\text { Güvenli Bilgi } \\
\text { Toplumu İçin Strateji }\end{array}$ \\
\hline $\begin{array}{l}\text { Aktörler arası } \\
\text { küresel iş birliği } \\
\text { gerekmektedir. }\end{array}$ & $\begin{array}{l}\text { İnternetin zararlı ve } \\
\text { yasal olmayan } \\
\text { içeriğinden } \\
\text { kaynaklanan } \\
\text { sorunlarla } \\
\text { mücadelede küresel } \\
\text { iş birliği } \\
\text { gerekmektedir. }^{73}\end{array}$ & $\begin{array}{c}\text { Bir ülkede ilk saldırı } \\
\text { işaretleri hakkında anında } \\
\text { bilgi alışverişi yoluyla } \\
\text { Birlik genelinde erken uyarı } \\
\text { sağlamak için iş birliği } \\
\text { şarttır. Bu nedenle, Avrupa } \\
\text { Birliği içindeki CERT } \\
\text { sistemi ile iş birliği acil bir } \\
\text { konu olarak } \\
\text { güçlendirilmelidir. }^{74}\end{array}$ & $\begin{array}{l}\text { Aktörler arası } \\
\text { iş birliği } \\
\text { geliştirilmelidir } \\
\text { (md.5). }\end{array}$ & $\begin{array}{c}\text { Ağın ve bilgi } \\
\text { güvenliğinin küresel } \\
\text { boyutu, hem } \\
\text { uluslararası düzeyde } \\
\text { hem de üye devletler ile } \\
\text { koordineli olarak NIS } \\
\text { konusunda küresel } \\
\text { iş birliğini geliştirme } \\
\text { çabalarını artırmaya } \\
\text { zorlamaktadır. }\end{array}$ \\
\hline
\end{tabular}

Tablo 5 $5_{\mathrm{b}}$ : 2013 Strateji Belgesi ve Sonrası İşbirliği Unsuru

\begin{tabular}{|c|c|c|c|c|}
\hline $\begin{array}{c}2013 \\
\text { Siber Güvenlik } \\
\text { Strateji Belgesi }\end{array}$ & \begin{tabular}{|c|}
2015 \\
Dijital Tek Pazar \\
Stratejisi
\end{tabular} & $\begin{array}{c}2016 \\
\text { NIS Direktifi }\end{array}$ & $\begin{array}{c}2017 \\
\text { Revize Edilmiş } \\
\text { Siber Güvenlik } \\
\text { Strateji Belgesi }\end{array}$ & $\begin{array}{c}2019 \\
\text { Siber Güvenlik } \\
\text { Yasası }\end{array}$ \\
\hline $\begin{array}{c}\text { AB'de siber } \\
\text { dayanıklılığ } 1 \text { teşvik } \\
\text { etmek için, hem kamu } \\
\text { yetkilileri hem de özel } \\
\text { sektör yeteneklerini } \\
\text { geliştirmeli ve etkin bir } \\
\text { şekilde iş birliği } \\
\text { yapmalıdır. }\end{array}$ & $\begin{array}{c}\text { Etkin bir dijital } \\
\text { tek pazar için } \\
\text { aktörler arası } \\
\text { iş birliği } \\
\text { güçlendirilmelidir. }\end{array}$ & $\begin{array}{c}\text { Siber krizlere } \\
\text { yönelik etkin bir } \\
\text { iş birliği grubu } \\
\text { oluşturulmalıdır } \\
(\mathrm{md} .4,5) .\end{array}$ & $\begin{array}{c}\text { Siber güvenlik } \\
\text { bağlamında } \\
\text { uluslararası } \\
\text { iş birliğinin tesisi } \\
\text { önemlidir. }\end{array}$ & $\begin{array}{c}\text { Üye devletler, } \mathrm{AB} \\
\text { kurumları ve } \\
\text { ajansları arasında } \\
\text { iş birliği } \\
\text { güçlendirilmelidir } \\
\text { (md.6). }\end{array}$ \\
\hline
\end{tabular}

Sonuç olarak, bilgi ve iletişim teknolojilerine yönelik ilgisinin başlangıç noktasını teşkil eden 1985 yılından günümüze $\mathrm{AB}$, ortaya koyduğu önemli belgeler ve kurumsal yapıların oluşturulması bağlamında siber güvenlik politikasını geliştirip, güçlendirmeye odaklanmaktadır. Bu noktada AB'nin hem bu alandaki direktif, strateji, çerçeve kararları gibi dokümanları ekseninde siber güvenliğe sosyo-ekonomik odaklı

${ }^{73}$ European Commission, "Illegal and Harmful", p. 17, 25.

${ }^{74}$ European Commission, "Network and Information", p. 21.

${ }^{75}$ European Commission, "Cybersecurity Strategy", p. 5. 
Avrupa Birliği’nin Siber Güvenlik Politikası:

Kurumsalcılık mı Tutarlılık mı?

yaklaştığı hem de siber güvenlik politikasının temel olarak beş temel amaç üzerine inşa edildiği görülmektedir. Bir diğer ifadeyle, 1985 yılından günümüze kadar ortaya konan dokümanlar ve özelde siber güvenlikle ilişkili belgeler çerçevesinde siber güvenliğe ilişkin sosyoekonomik yaklaşım ve beş temel hedef devam etmektedir.

\section{Tarihsel Kurumsalcılık Teorisi ve Tutarlılık Yaklaşımının/ Modelinin Avrupa Birliği ve Siber Güvenlik Denklemindeki Analizi}

Avrupa Birliği sahip olduğu resmî ve resmî olmayan kurumlanı çerçevesinde bir bütün olarak kurumsalcılık teorisinin sunduğu önermelerin uygulanması açısından önemli bir test sahasını teşkil etmektedir. ${ }^{76} \mathrm{AB}$ politika yapımında büyük öneme sahip olan kurumlar, sadece fiziki yapılar değil, resmî kurallar, prosedürler, aktörlerin davranışlarını ve politika seçimleri etkileyen uygulamalardır. ${ }^{77} \mathrm{Bu}$ minvalden hareketle, siber güvenlik alanında kurulan kurumların ve ortaya konan belgelerin $\mathrm{AB}$ 'nin siber güvenlik politikası üzerindeki etkisi incelenmiş ve bu doğrultuda tarihsel kurumsalcılığın altını çizdiği ve başta alınan kararların veya uygulanan politikaların daha sonraki kararlar/politikalar üzerinde etki ettiğini tanımlayan yol/izlek bağımlılı̆̆ının doğrulandığı görülmüştür. Öyle ki analiz edildiği üzere, AB'nin bilgi ve iletişim teknolojilerine yönelik ilgisinin ilk kez görüldüğü 1985 yılında yayımlanan Beyaz Kitap'tan 2019 yılında yürürlüğe giren Siber Güvenlik Yasası'na kadar geçen 34 y1l içerisinde, AB'nin siber güvenliğe yönelik yaklaşımı sosyo-ekonomik merkezlidir ve siber güvenlik politikası; ekonomik maksimizasyonun sağlanması, temel hakların korunması, siber suçları/saldırıların önlenmesi, dijital sisteme yönelik güven unsurunun artırılması ve aktörler arasında iş birliğinin güçlendirilmesini içeren beş temel hedefe dayanmaktadır. Bir diğer ifadeyle, süreç içerisinde yapılan tercihlerin -sosyo-ekonomik yaklaşım sergileme ve beş ana hedef- daha sonraki zamanda da devam ettiği ve sonraki tercihler üzerinde etkili olduğu görülmektedir.

\footnotetext{
${ }^{76}$ Ben Rosamond, Theories of European Integration, London: Palgrave, 2000, p. 114.

${ }^{77}$ Hall and Taylor, "Political Science", pp. 939-940.
} 
658

Güvenlik Stratejileri

Cilt: 16

Sayı: 35

Dolayısıyla geçen 34 yıl zarfinda AB'nin siber güvenlik politikasındaki kurumsal ve siyasa tercihleri, tarihsel kurumsalcilığın ortaya koyduğu yol bağımlılı̆̆ ve hâkim yapıya uyum sağlanması zarfindaki kenetlenme etkisi çerçevesinde değişmeyen ve kalıcı bir düzlemde devam etmiştir.

Teorinin ortaya koyduğu politika yollarının, kararların ve tercihlerin kritik dönemeçler zarfinda değişebileceği ve hatta yeniden tanımlanabileceğini ele alan kesintiye uğramış denge mekanizması çerçevesinde $\mathrm{AB}$, siber güvenlik politikalarına etki edecek iki önemli kritik dönemeç/katalitik olay yaşamıştır. Bunlardan ilki, 2007 yılında gerçekleşen ve Rusya kaynaklı olduğu düşünülen Estonya'nın bilgi ve iletişim altyapısına yönelik siber saldırılar iken ${ }^{78}$ ikincisi ise 1 Aralık 2009 tarihinde yürürlüğe giren Lizbon Antlaşması'dır. Mevzubahis iki kritik dönemeç çerçevesinde $A B$ 'nin siber güvenliğe ilişkin sosyoekonomik odaklı yaklaşımında herhangi bir değişim yaşanmamıştır. İlk kritik dönemeçte, $\mathrm{AB}$ kesintili denge mekanizması çerçevesinde politika değiştirmek yerine ulusal güvenlik tehdidi ve bir savunma meselesi olarak tanımlanan bu şok krize, var olan politikası çerçevesinde cevap vermiş ve söz konusu olayı tek pazarın işleyişine yönelik bir risk algısı bağlamında yorumlamıştır. Öyle ki bu yaklaşımının değişmemesi durumu, Maastricht Antlaşması ile hayata geçen sütunlu yapı sistemine son veren ve $A B$ 'ye tüzel kişilik kazandıran ve dolayısıyla $A B$ mimarisinde köklü değişimler yapan Lizbon Antlaşması çerçevesinde de devam etmiştir. AB'nin hangi politika alanına dâhil olabileceğini ve söz konusu alanlara ne ölçüde katılabileceğini yetki kataloğu çerçevesinde belirleyen Lizbon Antlaşması çerçevesinde üç ana ve iki spesifik kategorizasyon söz konusudur. ${ }^{79}$ Bunlardan ilki; gümrük birliği, iç pazarın

${ }^{78}$ Mehmet, E., Erendor, "Risk Toplumu ve Refleksif Modernleşme Çerçevesinde Siber Terörizm: Tanımlama ve Tipoloji Sorunu", Cyberpolitik Journal, 2016, Cilt 1, Sayı 1, 114-133, s. 120.

79 ABİHA, 2012, md.2, https://www.ab.gov.tr/files/pub/antlasmalar.pdf, (Erişim Tarihi: 30.04.2020); İlke Göçmen, Avrupa Birliği Maddi Hukuku, Seçkin Yayıncılık, Ankara, 2017, s. 120; Mehmet H. Bayram, Avrupa Birliği Hukuku Dersleri, Seçkin Yayıncılık, Ankara, 2015, s. 93; Sanem Baykal ve İlke Göçmen, Avrupa Birliği Kurumsal Hukuku, Seçkin Yayıncılık, Ankara, 2016, s. 128. 
Avrupa Birliği’nin Siber Güvenlik Politikası:

Kurumsalcılık mı Tutarlılık mı?

işleyişindeki rekabet kurallarının oluşturulması, avro alanına yönelik para politikası, ortak balıkçılık politikası çerçevesinde biyolojik deniz kaynaklarının koruma altına alınması, ortak ticaret politikası gibi alanları kapsayan ve sadece AB'nin bağlayıcı düzenleme yapıp, tasarrufları kabul ettiği münhasır yetkidir. ${ }^{80}$ Diğeri, AB'nin yetkileri üye devletlerle paylaştı̆̆1; iç pazar, ekonomik, sosyal ve bölgesel uyum, çevre, tüketicinin korunması, taşımacılık, enerji gibi alanları içeren paylaşılan yetkidir. ${ }^{81}$ Üye devletlerin eylemlerini desteklemek, koordine etmek ve tamamlamak amaciyla AB'nin eylemde bulunabildiği ancak tasarruf çıkaramadığı insan sağlığının korunması ve iyileştirilmesi, kültür, turizm, eğitim ve sanayi gibi alanları tazammun eden destekleyici, koordine edici ve tamamlayıcı yetki ise üçüncü ana kategori altında bulunmaktadır. ${ }^{82}$ Öte yandan, spesifik kategorizasyon altında AB'nin üye devletlerin ekonomi ve istihdam politikalarını koordine edici eylemleri ve yetkilerinin oldukça sınırlı olduğu ortak dış ve güvenlik politikası yer almaktadır. ${ }^{83}$ Sonuç olarak, bu kategorizasyon ekseninde $\mathrm{AB}$ yetkilerinin sosyo-ekonomik merkezli alanlarda olduğu görülmekte ve hem bu statik yapı hem de AB'nin içinde taşıdığ 1 ve daha belirleyici özellik gösteren hükümetlerarası nitelik bağlamında AB'nin siber güvenlik alanında da sosyo-ekonomik bir yaklaşım sergilediği, kritik dönemeç ekseninde politika değişikliğine gidemediği ve bu noktada tarihsel kurumsalcılığın ortaya koyduğu kesintili denge mekanizmasıyla örtüşmediği görülmektedir.

Analiz edildiği üzere, bir kurumun faaliyetleri ekseninde olumlu geri bildirimler alabildiği ve söz konusu olumlu geri bildirimler zarfında kurumun yetkilerinin arttığ 1 olumlu geri bildirim döngüsü ise tarihsel kurumsalcılığın odaklandığı bir diğer mekanizmadır. AB'nin siber güvenlik politikaları çerçevesinde faaliyet gösteren Avrupa Siber Suç Merkezi’nin (EC3) ve Avrupa Ağ ve Bilgi Güvenliği Ajansı'nın (ENISAA)

\footnotetext{
${ }^{80}$ ABİHA, md. 2(3), 2(4).

${ }^{81}$ ABİHA, md. 2(2), 4(2).

${ }^{82}$ ABİHA, md. 2(5), 6.

${ }^{83}$ ABİHA, md. 2(3), 2(4).
}

\section{9}

Güvenlik Stratejileri

Cilt: 16

Say1: 35 
660

Güvenlik Stratejileri

Cilt: 16

Sayı: 35

yetkilerinin peyderpey artırılarak güçlendirilmesi ve 2019 yılında yürürlüğe giren Siber Güvenlik Yasası çerçevesinde ENISSA'nın daimi bir siber güvenlik ajansına dönüştürülmesi olumlu geri bildirim mekanizmasının işlerliğini doğrulamaktadır.

Öte yandan, tutarlılık yaklaşımının ana kurumsal prensiplerden biri haline dönüştüğü görülmektedir. ${ }^{84}$ Nitekim Maastricht Antlaşması, söz konusu yaklaşımın altını çizmektedir. Buna göre: “ Birlik; dış ilişkiler, güvenlik, ekonomi ve kalkınma politikaları çerçevesinde bir bütün olarak dışsal faaliyetlerin tutarlılığını garanti altına almalıdır". ${ }^{85}$ Ayrıca, Maastricht Antlaşması'ndan itibaren Avrupa güvenliği ekseninde tutarlı bir yaklaşım geliştirmenin önemine değinilmektedir. ${ }^{86} 2013$ yılında Avrupa Komisyonu tarafindan yayımlanan "AB Siber Güvenlik Strateji" belgesi ise tutarlılık yaklaşımının somut bir zemine oturtulmasına ilişkindir. ${ }^{87}$ Ancak kritik bilgi altyapısının korunması, siber suçlar ve siber savunma şeklinde üç temel faaliyet alanını kapsayan belge çerçevesinde kademeli bir şekilde koordinasyonun geliştirilmesi amaçlansa da hala bu üç boyut birbirinden ayrı olarak ele alınmaktadır. ${ }^{88}$ Diğer taraftan, Avrupa Güvenlik Gündemi'nde AB'nin iç güvenliği ve küresel güvenliğinin birbiriyle bağımlı ve bağlantılı olduğu, dolayısıyla AB'nin iç ve dış boyutlar çerçevesinde kapsamlı ve tutarlı faaliyetlere dayanması gerekliliğinin altı çizilmektedir. ${ }^{89} 2016$ yılında yayımlanan "Hibrit Tehditlere Karşı Ortak Çerçeve" içerisinde de tutarlılık yaklaşımının izleri görülmekte ve söz konusu belge doğrultusunda

${ }^{84}$ Cremona, "Coherence", p. 13.

${ }^{85}$ Maastricht Treaty, Article C.

${ }^{86}$ European Council, "Tampere Council Conclusions", 1999, https://www.europarl. europa.eu/summits/tam_en.htm\#c, (Erişim Tarihi: 02.04.2020); European Commission, "Practical Proposals".

${ }^{87}$ Elaine Fahey, "EU'S Cybercrime and Cyber Security Rule-Making: Mapping the Internal and External Dimensions of EU Security", European Journal of Risk Regulation, Vol 5, No 1, 46-60, pp. 48-49.

${ }^{88}$ George Christou, Cybersecurity in the European Union. Resilience and Adaptability in Governance Policy, Palgrave, London, 2016, pp. 27-32.

${ }^{89}$ European Commission, "The European Agenda". 
Avrupa Birliği’nin Siber Güvenlik Politikası:

Kurumsalcılık mı Tutarlılık mı?

hibrit tehditlere karşı ilgili tüm aktörler arasında sinerjinin ve koordinasyonun yaratılması gerekliliğine değinilmektedir..$^{90} 2017$ yılında Avrupa Komisyonu tarafindan yayımlanan revize edilmiş “ Siber Güvenlik Strateji” belgesinde ise ENISA'nın daha güçlü bir danışmanlık rolü ifa edeceği ve bu bağlamda sektörel girişimler ve NIS Direktifi arasında tutarlılığ 1 destekleyeceği ifade edilmektedir. ${ }^{91}$ Son olarak, 27 Haziran 2019'da yürürlüğe giren "Siber Güvenlik Yasası" ekseninde ENISA'nın faaliyetlerinin ulusal ve $A B$ düzlemindeki politikalarla tutarlı olması gerektiği ve $\mathrm{AB}$ bağlamında daha koordineli bir siber güvenlik yaklaşımına olan ihtiyaç ortaya konmaktadır. ${ }^{92}$

Görüldügü üzere tutarlılık, AB'nin siber güvenliğe yönelik yaklaşım ve politikası zarfında ortaya konan önemli bir gerekliliği yansitmaktadır. Mevzubahis gereklilik; üye devletlerin, kurumların ve uluslararası partnerlerin de dâhil olduğu tüm taraflar bağlamında bütüncül bir çabanın gösterilmesine ilişkin ortak bir yaklaşımı ifade etmektedir. ${ }^{93}$ Nitekim siber güvenlik son derece hassas, kurumsal koordinasyon ve ortak yaklaşım tesis edilmesi gereken bir alandır. Ancak söz konusu alana ilişkin üye devletlerin yaklaşımlarındaki farklılık dikkati çekmektedir. Öyle ki üye devletlerden Almanya, Fransa, Hollanda ve İtalya mevcut $\mathrm{AB}$ siber güvenlik çerçevesinden daha öteye gitmek isterken birçok üye devlet, bölgesel iş birliğini tercih etmektedir. Öte yandan, Fransa siber güvenliğe askerî ve istihbarat odaklı yaklaşırken Almanya ve Hollanda sivil ve hukuk temelli yaklaşmakta, Estonya ise bu iki yaklaşım arasında denge kuran bir bakış açısı sergilemektedir. ${ }^{94}$ Bununla beraber, eylemsel olarak da ortak adımların atılmadı̆̆

\footnotetext{
${ }^{90}$ European Commission, "Joint Framework on Countering Hybrid Threats", 2016, https://eur-lex.europa.eu/legal-content/EN/TXT/?uri=CELEX\%3A52016JC0018, (Erişim Tarihi: 22.04.2020).

${ }^{91}$ European Commission "Resilliene".

${ }^{92}$ European Commission, "Cyber SecurityAct"; European Commission, "Regulation on ENISA".

${ }^{93}$ European Commission, "Cybersecurity Strategy".

94 Akyeşilmen, "Siber Politika", s. 135.
}

\section{1}

Güvenlik Stratejileri

Cilt: 16

Say1: 35 
Güvenlik Stratejileri

Cilt: 16

Sayı: 35

görülmektedir. Nitekim Vişegrad devletleri ${ }^{95}$ ve Avusturya özelinde kendi Bilgisayar ve Acil Müdahale Ekipleri (CERT) bağlamında iş birliğinin geliştirilmesi için 2013 yllında "Merkez Avrupa Siber Güvenlik Platformu" kurulmuştur. ${ }^{96}$ Dolayısıyla, farklılaşan yaklaşımlar ve eylemler bağlamında tutarlılık ekseninde ortaya çıkan bu sorun, hem siyasi tercihler ve siber güvenlik ile ilgili faaliyetlerin yönetilmesindeki farklılık hem de diğer devletlerle bilgi paylaşımı için kurumsal bir çerçeve gerektiren mekanizma eksikliğiyle ilişkilidir ki bilginin toplanması ve paylaşımına ilişkin bir anlaşma da bulunmamaktadır. Ayrıca, devletler siber güvenlikte iş birliğinin sağlanması ekseninde farklı modellere sahiptir. ${ }^{97}$ Üstüne üstlük, üye devletlerin mevcut ulusal siber güvenlik stratejileri incelendiğinde, bu alanın bir öncelik haline getirilmesi, gerekli altyapının sağlanmasına ilişkin finansal kapasite ekseninde de farkl111klar bulunduğu gözlemlenmektedir.

Diğer taraftan, siber güvenliğin sağlanmasında tutarlı olunmasına dair kurumsal koordinasyon ve ortak bir yaklaşımın geliştirilmesi için aktörler arasında iş birliği gerekliliğine ilişkin yapılan retorik vurgu göz önüne alındığında, ${ }^{98} 2016$ Ağustos ayında yürürlüğe giren NIS Direktifi'nde aktörler arası iş birliğini güçlendirmeye yönelik bir "İşbirliği Grubu (Cooperation Group)" önerisinin sunulması ve 2018 y1lındaki Mutabakat Zaptı çerçevesinde ENISA, Avrupa Savunma Ajansı (EDA), EC3 ve CERT-EU'nun siber sorunların bertaraf edilmesine yönelik iş birliğini arttırma kararı almaları tutarlılık yaklaşımını yansıtmaktadır. ${ }^{99}$

${ }^{95}$ Vişegad devletleri; askerî, ekonomik ve enerji alanlarında iș birliğinin sürdürülmesi amaciyla oluşturulan Vişegrad grubundaki Çekya, Macaristan, Polonya ve Slovakya'yı içeren dört Orta Avrupa devletini kapsamaktadır.

${ }^{96}$ National Security Authority, "Central European Platform for Cybersecurity", 2018, https://www.nbu.gov.sk/en/cyber-security/partnership/central-european-platform-forcybersecurity/index.html, (Erişim Tarihi: 25.04.2020).

${ }^{97}$ Charles Guitton, "Cyber Insecurity as a National Threat: Overreaction from Germany, France and the UK?", European Security, 2013, Vol 22, No 1, 21-35., p. 25, 27.

${ }^{98}$ European Commission, "Cybersecurity Strategy"; European Commission, "Resilliene"; European Commission, "Cyber Security Act".

${ }^{99}$ NIS Directive, 2016, https://eur-lex.europa.eu/eli/dir/2016/1148/oj, (Erişim Tarihi: 
Avrupa Birliği’nin Siber Güvenlik Politikası:

Kurumsalcılık mı Tutarlılık mı?

Öte yandan, kritik bilgi altyapılarının özel sektörün elinde olduğu düşünüldüğü zaman, özel sektörle geliştirilen/geliştirilmeye çalışılan iş birliği belirgin bir öneme sahiptir. Nitekim, üye devletlerin kapasitelerinin ve altyapılarının uyumlaştııılması ve söz konusu aktörlerin kamu ve özel sektörle iş birliği zemini oluşturmasına vurgu yapılmaktadır. ${ }^{100} \mathrm{AB}$ kurumları ve üye devletlerin partneri olarak, gündem belirleyici ve farkındalığı artırıcı özelliğiyle siber güvenlik alanında merkezî bir rol ifa eden özel sektör arasında iş birliğinin güçlendirilmesi, sektörden sektöre farklı1ık arz etmektedir. Örneğin, finans sektörü iş birliğine oldukça açıkken telekomünikasyon sektörü ise bilgi değişiminin rekabet avantajının aşınmasına yol açabileceği endişesiyle daha kapalıdır. ${ }^{101}$ Bununla beraber, çıkarların farklılaşması nedeniyle özel ve kamusal sektör arasındaki iş birliği bağlamında da problemler söz konusudur. Bu noktada, kamusal sektör için güvenlik önceliklendirilirken özel sektör ise verimlilik ve kâr maksimizasyonuna yoğunlaşmaktadır. ${ }^{102}$ Dolayısıyla çıkarların farklılaşması ve uyuşmazlığı durumu yaşanmakta ve bu husus siber güvenlik alanına da yansımaktadır.

Özetle, hem ortak bir güvenlik anlayışı hem de kurumsal koordinasyon ve iş birliği ekseninde tutarlılığın güçlendirilmesine yönelik teşebbüslerin tam anlamıyla somut bir sonuca ulaşmadığ görülmektedir. $\mathrm{Bu}$ noktada, kurumlar arasında açık bir şekilde belirlenmiş sorumluluk alanları, hesap verebilirlik eksikliği ${ }^{103}$ ve

09.04.2020).

${ }^{100}$ Ibid.

${ }^{101}$ Giampiero Giacomello, "Introduction: Security In Cyberspace", Giampiero Giacomello (Edt.), Security in Cyberspace- Targeting Nations, Infrastructures, Individuals, Bloomsbury Academic, London, 2014, 1-20, p. 3.

${ }^{102}$ Myriam Dunn-Cavelty and Manuel Suter, "Public-Private Partnerships are no Silver Bullet: An Expanded Governance Model For Critical Infrastructure Protection", International Journal of Critical Infrastructure Protection, 2009, pp. 1-3, https://www.files. ethz.ch/isn/106323/PPP_no_silver_bullet.pdf, (Erişim Tarihi: 29.04.2020).

103 Annegret Bendiek, "European Cyber Security Policy", 2012, https://www.swpberlin.org/fileadmin/contents/products/research_papers/2012_RP13_bdk.pdf, (Erişim Tarihi: 19.04.2020). 
664

Güvenlik Stratejileri

Cilt: 16

Sayı: 35

AB'nin uluslarüstü ve hükümetlerarası niteliği doğrultusunda parçalı bir mekanizma bulunduğu belirtilmektedir. ${ }^{104}$ Öte yandan, kurumlar arası ve kurumların kendi içinde devam eden koordinasyon sorunu bulunmaktadır. Ek olarak, üye devletler ve $\mathrm{AB}$ kurumları arasında iş birliğinin güçlendirilememesine ilişkin ortaya çıkan sorun, üye devletler arasında yaşanan koordinasyon sorunu ile iç içe geçmekte ve daha da önemlisi üye devletler, AB'nin siber güvenlik alanında yetki gücünün güçlendirilmesi hususuna olumlu bakmamaktadır. ${ }^{105}$ Ortak bir güvenlik anlayışının inşa edilmesine ilişkin çabaya ve retorik vurguya rağmen, AB'nin, üye devletleri bu alanda entegre olmanın önemi konusunda ikna etmekte yetersiz olduğu ve söz konusu alanda faaliyet göstermeye çalışan kurumların yetkilerinin ise oldukça kısır kaldığ görülmektedir. AB'nin siber güvenlik alanındaki tutarlılığına ilişkin ortaya çıkan durum ise tablo 6'da şematize edilmektedir.

Sonuç olarak, tarihsel kurumsalcıllk teorisinin ortaya koyduğu mekanizmalarla büyük oranda örtüşen $\mathrm{AB}$ 'nin siber güvenlik politikalarının, kurumsallaşma merkezli bir gelişim gösterdiği, ne var ki söz konusu politikanın bütüncül bir tutarlılığı yansıtmadığı görülmektedir. Aslında AB'nin siber güvenliğe ilişkin sosyo-ekonomik yaklaşımının ve beş temel hedefinin 34 yıldır devam etmesi, AB-siber güvenlik denklemindeki tutarlılığa ilişkin bir gösterge olarak kabul edilebilir. Ancak çalışmanın teorik kısmında ortaya konan Avrupa

104 Alaxender Klimburg and Heli Tirmaa-Klaar,“Cybersecurity and Cyberpower: Concepts, Conditions and Capabilities for Cooperation for Action within the EU", 2011, p. 29, https://www.europarl.europa.eu/RegData/etudes/STUD/2011/433828/ EXPO-SEDE ET(2011)433828 EN.pdf, (Erișim Tarihi: 21.04.2020).

${ }^{105}$ Üye devletlerin, AB'nin siber güvenlik alanındaki yetkilerinin güçlenmesini istememelerinin altında, hükümetlerarası yapının etkisi ile yüksek ve alçak politika ayrımı bulunmaktadır. Alçak politika alanlarına giren ve daha işlevsel olan ekonomi, finans, maliye gibi alanlarda hem aktörler arası iş birliğinin sağlanması daha kolaydır hem de AB'nin bu alanda yetki sahibi olmasına yönelik üye devletlerden olumsuz sesler yükselmemektedir. Ancak güvenlik, savunma gibi daha siyasi ve hassas olan yüksek politika alanlarında hem iş birliğinin sağlanması daha zordur hem de çıkarları doğrultusunda üye devletler bu alanlarda $\mathrm{AB}$ 'ye yetki devretmeyi istememektedir. 
Avrupa Birliği’nin Siber Güvenlik Politikası:

Kurumsalcılık mı Tutarlılık mı?

Komisyonu'nun "çok daha etkili olma ve aktörler arası iş birliğinin oluşturulmasını" merkeze koyan tutarlılık kavramsallaştırması perspektifinde bakıldığında, kurumsal koordinasyon ve ortak güvenlik anlayışı ekseninde yatay, dikey ilişkiler bağlamında çelişkiler ve sorunlar bulunduğu görülmektedir. Öte yandan, her ne kadar AB siber güvenlik alanında tutarlılık yaklaşımını ön plana alan bir duruş sergilese de ve bu alanda faaliyet gösteren kurumların yetkileri artırılsa da heterojen yaklaşımlar ve AB'nin üzerine inşa edildiği içsel dinamikler nedeniyle söz konusu tutarlılık, önemli oranda retorik ve üye devletlerin imtiyazı altında kalmaktadır.

Tablo 6: Siber Güvenlik Alanında Tutarlılık ${ }^{106}$

\begin{tabular}{|c|c|c|}
\hline Tutarlılık & Yatay Eksen & Dikey Eksen \\
\hline Kurumsal Koordinasyon & $\begin{array}{l}\text { AB kurumları arasında } \\
\text { iş birliğinin gelişmesine } \\
\text { yönelik atıfta bulunan resmî } \\
\text { belgelerin, niceliksel olarak } \\
\text { arttı̆̆ ve siber güvenlik } \\
\text { alanında faaliyetler gösteren } \\
\text { kurumların kurulduğu } \\
\text { görülmektedir. } \\
\text { Yakın iş birliğine ilişkin } \\
\text { söylemler, teorik kalmakta } \\
\text { ve somut anlamda pratik } \\
\text { boyuta taşınmamaktadır. } \\
\text { Tutarlılık; finansal } \\
\text { kaynaklar ve alana yönelik } \\
\text { uzmanlardaki yetersizlik ve } \\
\text { karmaşık işbölümü } \\
\text { nedeniyle sınırlı } \\
\text { kalmaktadır. } \\
\\
\text { Özel sektör arasındaki } \\
\text { koordinasyonun büyük } \\
\text { oranda sağlandığına ilişkin } \\
\text { somut veriler } \\
\text { bulunmamaktadır. }\end{array}$ & $\begin{array}{c}\text { AB ve ulusal (üye devletler) düzleminde } \\
\text { iş birliğinin geliştirilmesine ilişkin somut } \\
\text { sorunlar bulunmaktadır. } \\
\text { Siber güvenlik, üye devletlerin imtiyazı } \\
\text { altında kalmaya devam etmektedir. } \\
\text { Bölgesel ve bölge-altı işbirliklerinin } \\
\text { geliştirilmesinde AB, parçalı bir yaklaşıma } \\
\text { sahiptir. } \\
\text { Siber güvenlik alanında ENISA ve EC3 } \\
\text { yeni yetkiler kazanmıştır. } \\
\text { Özel sektörün siber güvenlik alanında } \\
\text { iş birliğinin sağlanmasına ilişkin istekliliği } \\
\text { olmasına rağmen, bu durum sınırlı düzeyde } \\
\text { sağlanmaktadır. }\end{array}$ \\
\hline
\end{tabular}

${ }^{106}$ Helena Carrapico and Andre Barrinha, "The EU as a Coherent Security Actor?", JCMS, 2017, Vol 55, No 6, 1254-1272, p. 1263. 
666

Güvenlik

Stratejileri

Cilt: 16

Sayı: 35

\begin{tabular}{|c|c|c|}
\hline Ortak Güvenlik Anlayışı & $\begin{array}{l}\text { AB ve ulusal düzlemde } \\
\text { ortaya konan resmî belgeler } \\
\text { çerçevesinde siber tehditler } \\
\text { ve güvenliğin sağlanmasına } \\
\text { ilişkin teorik bazda ortak bir } \\
\text { noktada buluşulmaktadır. } \\
\text { Siber güvenliğe ilişkin ortak } \\
\text { bir anlayış bağlamında üye } \\
\text { devletlerin söylemleri ve } \\
\text { taahhütleri belirgin değildir. } \\
\\
\text { Özel sektörün siber } \\
\text { tehditlere ilişkin ortak bir } \\
\text { anlayışa sahip olup } \\
\text { olmadığına ilişsin somut } \\
\text { veriler bulunmamaktadır. } \\
\text { Önlem ve hazırlık } \\
\text { faaliyetleri çerçevesinde } \\
\text { benzer risk anlayıș1 } \\
\text { bulunmamaktadır. }\end{array}$ & $\begin{array}{c}\text { Siber güvenlikte merkezî bir rol oynamaları } \\
\text { çerçevesinde üye devletlerin sorumlulukları } \\
\text { artmaktadır. Ancak tüm üye devleler benzer } \\
\text { tehdit ve sorunları yaşamamaktadır. } \\
\text { Gelişim düzeyleri farklı olması nedeniyle } \\
\text { üye devletler, siber tehditlere ilişkin benzer } \\
\text { önlemler alamamakta ve bu tehditlere } \\
\text { yönelik benzer karşılık verememektedir. } \\
\text { Özel sektörün sadece bir bölümü, AB ve } \\
\text { ulusal düzlemde ortaya çıkan kaygıları } \\
\text { paylaşmaktadır. }\end{array}$ \\
\hline
\end{tabular}

\section{Sonuç}

AB; dış politika, savunma ve güvenlik merkezli oluşturulan bir proje olmasa da zaman içerisinde Birliğin, ekonomik entegrasyondan siyasi entegrasyona geçiş amacıyla hareket kabiliyetini güçlendirmeye çalıştığı ve özelde siber uzay kaynaklı tehditler bağlamında öne çıkan siber güvenliğin sağlanması konusunda politikalar takip ettiği ve bu alana ilişkin yoğun bir retorik vurgunun olduğu görülmektedir. $\mathrm{Bu}$ minvalden hareketle, özünde AB'nin siber güvenlik politikalarını tarihsel kurumsalcılık ve tutarlılık yaklaşımı çerçevesinde analiz ederek, bir kurumsallaşmanın $\mathrm{m} 1$ yoksa tutarlılığının $\mathrm{m} 1$ baskın geldiğini sorunsallaştırma amacıyla ortaya konan bu çalışma zarfında elde edilen ilk bulgu, hem $\mathrm{AB}$ ekseninde hem de ulusal düzlemde siber güvenliğe ilişin ortak bir kavramsallaştırma bulunmamasıdır. AB'nin bilgi ve iletişim teknolojilerine ilişkin ilgisinin ilk başlangıç noktasını oluşturulan 1985 yılında Avrupa Komisyonu'nun yayımladı̆̆1 Beyaz Kitap'tan 2019 yılında yürürlüğe giren Siber Güvenlik Yasası'na kadar geçen süredeki siber güvenlikle ilgili dokümanların incelenmesi doğrultusunda, AB'nin siber güvenlik politikasının ve bu alandaki hedeflerinin gelişim serüveni analiz edilmiştir. İncelenen belgeler çerçevesinde AB siber 
Avrupa Birliği’nin Siber Güvenlik Politikası:

Kurumsalcılık mı Tutarlılık mı?

güvenliğe, sosyo-ekonomik ve beş nihai hedef merkezli yaklaşmaktadır. $\mathrm{Bu}$ doğrultuda ikinci bulgu, AB'nin siber güvenlik alanına sosyoekonomik merkezli yaklaşımının ve ekonomik fayda/maksimizasyonun sağlanması, temel hakların korunması, siber suçları/saldırıların önlenmesi, dijital sisteme yönelik güven unsurunun artırılması ve aktörler arasında iş birliğinin güçlendirilmesini içeren beş nihai hedefinin, 1985 yılından günümüze devam ettiğinin görülmesidir. $\mathrm{Bu}$ durum ise tarihsel kurumsalc1lık teorisinin ortaya koyduğu ve başta alınan kararların, daha sonrakiler üzerinde etkili olacağını vurgulayan yol bağımlılığı mekanizmasıyla örtüşmektedir. Diğer taraftan $\mathrm{AB}$, siber güvenlik politikalarına etki edecek iki önemli kritik dönemeçten geçmiştir. Söz konusu ilk dönemeç, Estonya'ya yapılan siber saldırılar ve ikinci dönemeç noktası ise AB'nin kurumsal mimarisine önemli değişiklikler getiren Lizbon Antlaşması'dır. Estonya saldırısı sonrası AB yaklaşımında herhangi bir değişime yönelmemiş, üstüne üstlük, kurumsal yapıda büyük dönüşümlere yol açan ve bu noktada $\mathrm{AB}$ 'nin yetkilerinin kullanımı konusunda önemli bir mihenk taşı olan Lizbon Antlaşması'nın yetki kategorizasyonu ekseninde de $\mathrm{AB}$ yetkilerinin sosyo-ekonomik merkezli alanlarda olduğu görülmektedir. Dolayısıyla, AB'nin bu kritik dönemeçlere rağmen politika değişikliğine gitmeyerek siber güvenlik alanında sosyo-ekonomik odaklı yaklaşım sergilemeye devam etmesi ise teori bağlamında kritik dönemeçlerde politika değişikliğine gidebileceği savının temellendirildiği kesintiye uğramış denge mekanizmasının doğrulanmadığını göstermektedir ki bu da çalışma zarfinda elde edilen üçüncü bulguyu teşkil etmektedir. Dolayısıyla, AB'nin siber güvenlik alanında savunma odaklı bir politikaya yönelmesi, hem statik yapı bağlamında yetkilerinin sınırlarının değişmemesinden hem de bu alanda hükümetlerarası özelliğin baskın olmasından ötürü yakın gelecekte beklenebilir bir durum değildir. Öte yandan, siber güvenlik alanında faaliyet gösteren EC3 ve ENISA'nın yetkilerinin güçlendirilmesi çerçevesinde teorinin sunduğu olumlu geri bildirim mekanizmasının işler olduğu sonucuna ulaşılması ise bir diğer bulguyu oluşturmaktadır.

Tutarlık yaklaşımı çerçevesinde ise gerek kurumsal koordinasyon ve iş birliği gerek ortak güvenlik anlayışı bağlamında hem $A B$ ve ulusal düzlemde hem de özel sektör ekseninde sorunlar yaşandığı sonucuna 
668

Güvenlik Stratejileri

Cilt: 16

Say1: 35 ulaşılmıştır. Aslında AB, siber güvenlik alanında tutarlılığı merkeze koyan bir yaklaşıma haizdir ve bu alanda faaliyet gösteren kurumların yetkileri peyderpey artırılmaktadır. Lakin üye devletlerin söz konusu alanda $\mathrm{AB}$ 'nin kontrolüne ve yetkilerinin güçlendirilmesine ilişkin mukavemet göstermeleri, AB'nin üzerine kurulduğu dinamikler ve homojen olmayan yaklaşımlar doğrultusunda mevzubahis tutarlılık, retorik kalmakta ve imtiyaz büyük oranda üye devletlerin tekelinde bulunmaktadır. Bu noktada, neredeyse tamamen üye devletlerin imtiyazı altında bulunan siber güvenlik alanında Birlik yetkilerine ilişkin önemli bir değişim meydana gelmedikçe, Birliğin sosyo-ekonomik bir bağlamda hareket etmeye devam edeceği rahatlkkla öngörülebilmektedir. Ancak siber güvenlik alanı salt devletlerin yetkisi altına bırakılamayacak kadar karmaşık ve ulusötesidir.

Son kertede, AB'nin siber güvenlik politikaları tarihsel kurumsalcılık kuramının ortaya koyduğu çıktılarla büyük oranda uyuşması bağlamında kurumsallaşma merkezli bir gelişim göstermektedir. Fakat söz konusu politika ekseninde bütüncül bir tutarlılık söz konusu değildir. AB tutarlı olmaya çalışmakta ama bu husus, somut anlamda başarılmış gözükmemektedir. Bu noktada hem genel anlamda hem de siber güvenliğin sağlanması özelinde tutarlı bir AB'ne dönüşüm ihtiyacı bulunmaktadır.

\section{Summary}

Cyber security constitutes a new and popular area in contemporary security studies. Although the academic literature has not been focused on cyber security adequately for many years, it has been observed that security and cyberspace intersect at a common point following the development of information and communication technologies in a ground-breaking dimension and the interest in this field has increased recently. However, studies on the cyber security policy of the European Union (EU), which is an important actor in the international platform, has quite limited. Moving from this perspective, the cyber security policy of the European Union and the equation arises in the context of the cyber security phenomenon and the European 
Avrupa Birliği’nin Siber Güvenlik Politikası:

Kurumsalcılık mı Tutarlılık mı?

Union are analysed examined for finding out whether the equation is built on institutionalism or consistency.

Despite the contributions made by cyber space to human beings, it brings many problems because it includes all the actors which are related to the internet and communication technologies and its uncertain limit. In the context of these problems, the importance of the cyber security phenomenon for the European Union is increasing day by day and the policies regarding this field are carefully followed. On that note, it is seen that the EU approached cyber security with a socio-economic centre in the 34-year period started from the publication of the White Paper by the European Commission in 1985 to the Cyber Security Law which came into force in 2019. In addition, it was concluded that it tried to strengthen its mobility in cyber security field in line with five ultimate goals which includes ensuring economic benefits/maximization, protecting fundamental rights, preventing cyber-crime/attacks, increasing confidence in the digital system and strengthening cooperation among actors. This situation coincides with the concept of the "path dependency" of the historical institutionalism theory. On the other hand, the EU has gone through two important critical turns, one of which was the cyber-attack on Estonia in 2007 and the Lisbon Treaty, which came into force in 2009. However, despite these two important turning points, it is seen that the EU has not made a policy change and continues to approach the field of cyber security in a socio-economic manner. This does not match the theory's "punctuated equilibrium" mechanism. Additionally, increasing powers of ENISA and EC3 operating in the field of cyber security shows the functionality of the "positive feedback loop" of the theory.

The EU tries to be a coherent actor in the field of cyber security within the framework of institutional coordination and common security understanding facility. However, there are problems in strengthening coordination and cooperation and establishing a common understanding of cyber security between and within the EU, national and private sector. The lack of accountability of EU institutions, the difference in financial capacity of member states, the different approaches of member states in this field and the resistance against strengthening the powers of the EU

\section{9}

Güvenlik Stratejileri

Cilt: 16

Say1: 35 
Güvenlik Stratejileri

Cilt: 16

Sayı: 35

and the dominance of intergovernmental quality as a whole put off its coherency. As the cyber space has a very complex and ambiguous structure, it is vital to construct a consistent, holistic and collaborative approach that covers all stakeholders in the EU context. However, coherence remains rhetorical and grant in the field of cyber security is largely monopolized by member states.

In the last instance, the EU's cyber security policies have progressed an institutionalization-centred in the context of a great deal of harmony with the outcomes of the historical institutionalism theory. However, there is no holistic coherence in this policy field. Although the EU wants to be coherent both in general and in cyber security, it has not succeeded in concrete terms yet.

\section{Kaynakça}

Kitap

AKYEŞILMEN, Nezir, Siber Politika ve Güvenlik, Orion Yayınevi, Ankara, 2018.

BAYKAL, Sanem ve Göçmen, İlke, Avrupa Birliği Kurumsal Hukuku, Seçkin Yayıncılık, Ankara, 2016.

BAYRAM, H. Mehmet, Avrupa Birliği Hukuku Dersleri, Seçkin Yayıncılık, Ankara, 2015.

CHRISTOU, George, Cybersecurity in the European Union. Resilience and Adaptability in Governance Policy, Palgrave, London, 2016.

EILSTRUPP-SANGIOVANNI, Mette, Debates on European Integration, Palgrave, Houndmilss, 2006.

GÖÇMEN, İlke, Avrupa Birliği Maddi Hukuku, Seçkin Yayıncılık, Ankara, 2017.

PIERSON, Paul, Politics in Time: History, Institutions, and Social Analysis, Princeton University Press, NJ., 2004.

ROSAMOND, Ben, Theories of European Integration, Palgrave, London, 2000.

Makale

BULMER, Simon, "The Governance of the European Union: A New Institutionalist Approach", Journal of Public Policy, 1993, Vol 13, No 4, pp. 351-380.

CARRAPICO, Helena and Barrinha, Andre, "The EU as a Coherent Security Actor?", JCMS, 2017, Vol 55, No 6, pp. 1254-1272.

CREMONA, Marise, "Coherence through Law: What Difference will the Treaty of Lisbon Make?", Hamburg Review of Social Sciences, 2008, Vol 3, No 1, pp. 11-36.

DARICILI, B., Ali, “Türkiye'nin Siber Güvenlik Politikalarının Analizi; Türkiye'nin Siber Güvenlik Modeli için Öneriler”, TESAM Akademi Dergisi, 2019, Cilt 6, Sayı 2, ss. 11-33. 
Avrupa Birliği’nin Siber Güvenlik Politikası:

Kurumsalc1lık mı Tutarlılık mı?

ERENDOR, Mehmet, E., "Risk Toplumu ve Refleksif Modernleşme Çerçevesinde Siber Terörizm: Tanımlama ve Tipoloji Sorunu", Cyberpolitik Journal, 2016, Cilt 1, Say1 1, ss. 114-133.

FAHEY, Elaine, "EU'S Cybercrime and Cyber Security Rule-Making: Mapping the Internal and External Dimensions of EU Security", European Journal of Risk Regulation, 2014, Vol 5, No 1, pp. 46-60.

GIACOMELLO, Giampiero, "Introduction: Security In Cyberspace", Giampiero Giacomello (Edt.), Security in Cyberspace- Targeting Nations, Infrastructures, Individuals, Bloomsbury Academic, London, 2014, pp. 1-20.

GUITTON, Charles, "Cyber Insecurity as a National Threat: Overreaction from Germany, France and the UK?", European Security, 2013, Vol 22, No 1, ss. 21-35.

HALL, Peter and Taylor, Charles, "Political Science and the Three New Institutionalisms", Political Studies, 1996, Vol 44, No 2, pp.936-957.

KRASNER, Stephen D., "Approaches to the State: Alternative Conceptions and Historical Dynamics", Comparative Politics, 1984, Vol 16, No 2, pp. 223-246.

PIERSON, Paul, "Increasing Returns, Path Dependence, and the Study of Politics", American Political Science Association, 2000, Vol 94, No 2, pp. 251-267.

PIERSON, Paul and Skocpol, Theda, "Historical Institutionalism in Contemporary Political Science", Ira Katznelson, Helen Milner and Ada Finifter (Edt.), Political Science: The State of the Discipline, Norton Press, NewYork, 2002, pp. 693-721

POLLACK, Mark, "The New Institutionalism and EU Governance: The Promise and Limits of Institutionalist Analysis", Governance, 1996, Vol 9, No 4, pp. 429-458.

POLLACK, Mark, "The New Institutionalism and European Integration", Antje Wiener ve Thomas Diez (Edt.), European Integration Theory, Oxford University Press, NewYork, 2009, pp. 125-143.

POMORSKA, Karolina and Vanhoonacker, Sophie, "Europe as a Global Actor: Searching for a New Strategic Approach", JCMS, 2016, Vol 52, No 1, pp. 216-229.

SLIWINSKI, Feliks, "Moving beyond the European Union's Weakness as a Cyber Security Agent", Contemporary Security Policy, 2014, Vol 35, No 3, pp. 468-486.

THELEN, Kathleen, "Historical Institutionalism in Comparative Politics", Annual Review of Political Science, 1999, Vol 2, pp. 369-404.

\section{İnternet Kaynakları}

ABİHA, 2012, https://www.ab.gov.tr/files/pub/antlasmalar.pdf, (Erişim Tarihi: 30.04.2020).

BANGEMANN, Martin, "Recommendations to the European Council Europe and the Global Information Society", 1994, http://www.channelingreality.com/ Digital_Treason/Brussels_1995/Bangemann_report.pdf, (Erişim Tarihi: 13.03.2020).

BENDIEK, Annegret, "European Cyber Security Policy", 2012, https://www.swp-berlin. org/fileadmin/contents/products/research_papers/2012_RP13_bdk.pdf, (Erişim Tarihi: 19.04.2020).

COLLIER, R. Berrins and Collier, David, "Framework: Critical Junctures and Historical Legacies", 1991, https://polisci.berkeley.edu/sites/default/files/people/ u3827/Collier-Collier\%20SPA\%20Chap\%201.pdf, (Erişim Tarihi: 10.04.2020). 
Fulya KÖKSOY

672

Güvenlik

Stratejileri

Cilt: 16

Sayı: 35

CRAIGEN, Dan, Diakun-Thibault, Nadia and Purse, Randy, "Defining Cybersecurity", Technology Innovation Management Review, 2014, https://timreview.ca/ sites/default/files/article_PDF/Craigen_et_al_TIMReview_October2014.pdf, (Erişim Tarihi: 18.02.2020).

DUNN-CAVELTY, Myriam and Suter, Manuel, "Public-Private Partnerships are no Silver Bullet: An Expanded Governance Model For Critical Infrastructure Protection", International Journal of Critical Infrastructure Protection, 2009, https://www.files.ethz.ch/ isn/106323/PPP_no_silver_bullet.pdf, (Erişim Tarihi: 29.04.2020).

ENISA, "Overview of Cybersecurity and Related Terminology", 2017, https://www.enisa.europa.eu/publications/enisa-positionpapers-and-opinions/enisa-ove rview-of-cybersecurity-and-related-terminology, (Erişim Tarihi:03.05.2020).

ENISA, "About ENISA", 2020, https://www.enisa.europa.eu/about-enisa, (Erişim Tarihi: 12.04.2020).

European Commission, "Completing the Internal Market", 1985, https://eurlex.europa.eu/legal-content/EN/TXT/PDF/?uri=CELEX:51985DC0310\&from=EN, (Erişim Tarihi: 09.02.2020).

European Commission, "Illegal and Harmful Content on Internet", 1996, http://aei.pitt.edu/5895/1/5895.pdf, (Erişim Tarihi: 10.03.2020).

European Commission, "Network and Information Security: Proposal for A European Policy Approach", 2001, https://ec.europa.eu/transparency/regdoc/rep/1/2001/EN/12001-298-EN-F1-1.Pdf, (Erişim Tarihi: 11.03.2020).

European Commission, "Some Practical Proposals for Greater Coherence, Effectiveness and Visibility", 2006, https://ec.europa.eu/councils/bx20060615/ euw_com06_278_en.pdf, (Erişim Tarihi: 03.04.2020).

European Commission , "Strategy for a Secure Information Society", 2006, https://eurlex.europa.eu/legal-content/EN/TXT/HTML/?uri=LEGISSUM:124153a, (Erişim Tarihi: 03.04.2020).

European Commission, "Cybersecurity Strategy of the European Union: An Open, Safe and Secure Cyberspace", 2013, http://eeas.europa.eu/archives/docs/policies/eucyber-security/cybsec_comm_en.pdf, (Erişim Tarihi: 15.03.2020).

European Commission ${ }_{\mathrm{a}}$, "The European Agenda on Security", 2015, https://eurlex.europa.eu/legal-content/GA/TXT/?uri=CELEX:52015DC0185, (Erişim Tarihi: 17.03.2020).

European Commission b" A Digital Single Market Strategy for Europe", 2015, https://eur-lex.europa.eu/legal-content/EN/TXT/?uri=celex\%3A52015DC0192,

(Erişim Tarihi: 18.03.2020).

European Commission, "Joint Framework on Countering Hybrid Threats", 2016, https://eur-lex.europa.eu/legal-content/EN/TXT/?uri=CELEX\%3A52016JC0018, (Erişim Tarihi: 22.04.2020).

European Commission ${ }_{\mathrm{a}}$, "Resillience, Detterence and Defence: Building Strong Cyber Secuirty for the EU", 2017, https://eur-lex.europa.eu/legal-content/en/TXT/?uri= CELEX\%3A52017JC0450, (Erişim Tarihi: 14.04.2020).

European Commission b, "Cyber Security Act", 2017, https://eur-lex.europa.eu/legal- 
Avrupa Birliği’nin Siber Güvenlik Politikası:

Kurumsalc1lık mı Tutarlılık mı?

content/EN/TXT/HTML/?uri=CELEX:52017PC0477\&from=EN， (Erişim Tarihi: 19.04.2020).

European Commission, "Regulation on ENISA and on Information and Communications Technology Cybersecurity Certification and Repealing Regulation (Cybersecurity Act)", 2019, https://eur-lex.europa.eu/legal-content/EN/TXT/PDF/?uri=CELEX:32019R0881\& from=EN, (Erişim Tarihi:01.05.2020).

European Commission, "The Directive on Security of Network and Information Systems (NIS Directive)", 2020, https://ec.europa.eu/digital-single-market/en/networkand-information-security-nis-directive, (Erişim Tarihi: 17.03.2020).

European Council, "European Council Conclusions Corfu", 1994, http://aei.pitt.edu/1444/1/corfu_june_1994.pdf, (Erişim Tarihi: 09.03.2020).

European Council, "Tampere Council Conclusions", 1999, https://www.europarl. europa.eu/summits/tam_en.htm\#c, (Erişim Tarihi: 02.04.2020).

European Council, "Council Framework Decision on Attacks against Information Systems", 2005, https://eur-lex.europa.eu/legal-content/EN/TXT/PDF/?uri=CELEX: 32005F0222\&from=EN, (Erişim Tarihi: 11.03.2020).

European Parliament and Council, "Directive on the Protection of Individuals with Regard to the Processing of Personal Data and on the Free Movement of Such Data", 1995, https://eur-lex.europa.eu/legal-content/EN/TXT/?uri=CELEX\%3A31995L0046, (Erişim Tarihi: 10.03.2020).

European Parliament and Council, "Directive on the Concerning the Processing of Personal Data and the Protection of Privacy in the Electronic Communications Sector", 2002, https://eur-lex.europa.eu/legal-content/EN/TXT/PDF/?uri=CELEX:32002L0058 \&from=EN, (Erişim Tarihi: 11.03.2020).

European Parliament and Council, "Directive on the Retention of Data Generated or Processed in Connection with the Provision of Publicly Available Electronic Communications Services or of Public Communications Networks and Amending", 2006, https://eur-lex.europa.eu/legal-content/EN/TXT/PDF/?uri=CELEX:32006L0024 \&from=GA, (Erişim Tarihi: 11.03.2020).

European Parliament and Council, "Directive on Network and Information Systems across the Union", 2016, https://eur-lex.europa.eu/legal-content/EN/TXT/?uri=uriserv:OJ.L_. 2016.194.01.0001.01.ENG\&toc=OJ:L:2016:194:TOC, (Erişim Tarihi:15.04.2020).

Federal Ministry of the Interior, "Cyber Security Strategy for Germany", https://www.cio.bund.de/SharedDocs/Publikationen/DE/Strategische-

Themen/css_engl_download.pdf?_blob=publicationFile, (Erişim Tarihi: 09.03.2020).

HELMBRECHT, Udo, Purser, Steve and Ritter-Klejn, Maj, "Cyber Security: Future Challenges and Oportunities", 2012, https://www.btg.org/wp-content/uploads/2012 /01/ENISA-Cyber-Security-Report-2011.pdf, (Erişim Tarihi:03.05.2020).

KLIMBURG, Alaxender and Tirmaa-Klaar, Heli, "Cybersecurity and Cyberpower: Concepts, Conditions and Capabilities for Cooperation for Action within the EU", 2011, https://www.europarl.europa.eu/RegData/etudes/STUD/2011/433828/EXPOSEDE_ET(2011)433828_EN.pdf, (Erişim Tarihi: 21.04.2020).

LOCKWOOD, Matthew, Kuzemko, Caroline, Mitchell, Catherine and Hoggett, 


\section{Fulya KÖKSOY}

674

Güvenlik

Stratejileri

Cilt: 16

Sayı: 35
Richard, "Historical Institutionalism and the Politics of Sustainable Energy Transitions: A Research Agenda", 2016, https://core.ac.uk/download/pdf/ 43098859.pdf, (Erişim Tarihi: 19.02.2020).

Maastricht Treaty, 1992, https://europa.eu/european-union/sites/europaeu/files/docs/ body/treaty_on_european_union_en.pdf, (Erişim Tarihi: 21.03.2020).

Ministry of Digital Affairs, "National Framework of Cybersecurity Policy of the Republic of Poland for 2017-2022", 2017, https://www.enisa.europa.eu/topics/ national-cyber-security-strategies/ncssmap/strategies/govermental-program-for-protect ion-of-cyberspace-for-theyears-2011-2016-2013, (Erişim Tarihi:09.03.2020).

MISSIROLI, Antonio, "Towards An Eu Global Strategy: Background, Process, References", 2015, https://www.iss.europa.eu/sites/default/files/EUISSFiles/ Towards_an_EU_Global_Strategy_0_0.pdf, (Erişim Tarihi: 12.03.2020).

National Security Authority, "Central European Platform for Cybersecurity", 2018, https://www.nbu.gov.sk/en/cyber-security/partnership/central-european-platform-forcybersecurity/index.html, (Erişim Tarihi: 25.04.2020).

NIS Directive, 2016, https://eur-lex.europa.eu/eli/dir/2016/1148/oj, (Erişim Tarihi: 09.04.2020).

Single European Act, 1987, https://eur-lex.europa.eu/legal-content/EN/TXT/PDF/? uri=CELEX:11986U/TXT\&from=EN, (Erişim Tarihi: 10.03.2020).

Strategie Kybernetické Obrany ČR, 2018, http://www.acr.army.cz/assets/informacniservis/zpravodajstvi/strategie-kyberneticke-obrany.pdf, (Erişim Tarihi: 07.05.2020).

TRAUNER, Florian, "The Internal-external Security Nexus: More Coherence under Lisbon?", 2011, https://www.ies.be/files/op89_The_internal-external_security_nexus.pdf, (Erişim Tarihi: 12.03.2020). 